\title{
A economia solidária: Um movimento internacional
}

The Solidarity Economy: An International Movement

L'économie solidaire: un mouvement international

Jean-Louis Laville

\section{CpenEdition}

\section{Journals}

Edição electrónica

URL: http://journals.openedition.org/rccs/381

DOI: $10.4000 /$ rccs.381

ISSN: 2182-7435

\section{Editora}

Centro de Estudos Sociais da Universidade de Coimbra

Edição impressa

Data de publição: 1 Março 2009

Paginação: 7-47

ISSN: 0254-1106

\section{Refêrencia eletrónica}

Jean-Louis Laville, «A economia solidária: Um movimento internacional », Revista Crítica de Ciências Sociais [Online], 84 | 2009, colocado online no dia 01 dezembro 2012, criado a 19 abril 2019. URL http://journals.openedition.org/rccs/381 ; DOI : 10.4000/rccs.381 


\section{JEAN-LOUIS LAVILLE}

\section{A economia solidária: Um movimento internacional}

$\mathrm{O}$ artigo mostra como em diferentes contextos nacionais e continentais se gerou um movimento de economia solidária. A diversidade de práticas no seio da sociedade civil local e internacional merece ser sublinhada. Esta geração de iniciativas, simultaneamente políticas e econômicas surgidas nas últimas décadas, prolonga e renova a economia social, oferecendo, assim, propostas concretas para uma outra economia, num período de crise capitalista. Como tal, não pode ser ignorada na busca de um modelo económico e de uma acção pública renovada.

Palavras-chave: Economia solidária, cooperativismo, associativismo, auto-gestão, democracia participativa, economia popular, a outra economia.

As associações e as cooperativas registam uma nova presença na economia e na política no último quartel do século XX. Como afirma L. Prouteau, "um dos traços mais importantes das transformações que afectaram o mundo associativo no último quarto de século reside, sem dúvida, no crescimento em força das suas actividades económicas" (Prouteau, 2003; Demoustier et al., 2003). O segundo traço marcante é o surgimento de uma sociedade civil mundial definida como a esfera de relações e de actividades transnacionais criadas por actores colectivos - movimentos sociais, redes e organizações da sociedade civil - que são independentes dos governos e das empresas privadas e que funcionam fora do alcance dos Estados e dos mercados. Este artigo caracteriza detalhadamente as formas deste processo multidimensional, sublinhando as questões novas que as associações e cooperativas, nalgumas das suas reconfigurações actuais, colocam. Actualmente, como no passado, é preciso fazer incidir a luz sobre este ângulo morto, no qual há que procurar novas fronteiras entre economia e política. 


\section{Dos colectivos voluntários aos colectivos forçados}

Durante os Trinta Gloriosos, de 1945 a 1975, o recurso à democracia representativa e à negociação colectiva constituiu o meio institucional que permitia que o conflito de classes pudesse ser reabsorvido por uma compatibilidade, ao nível macro-social, entre crescimento e solidariedade. Neste contexto, os sindicatos apareciam como a expressão da força operária colectiva. Os direitos conquistados graças a eles materializaram-se através de formas de participação indirecta, de amplitude variável consoante os países. Os poderes destes sindicatos foram alargados à consulta em matéria económica, com os conselhos de empresa na Alemanha ou os comités consultivos na Grã-Bretanha. Porém, na maior parte dos países, as atribuições dos representantes eleitos dos assalariados conduziram ao reconhecimento de uma concertação limitada ao domínio social: condições de trabalho, higiene e segurança, formação profissional, remuneração, obras sociais. Em suma, no compromisso fordista, o contra-poder sindical facilitou simultaneamente a humanização e a aceitação do taylorismo. "A instrumentalização do conflito de classes" (Dahrendorf, 1972) permitiu o reconhecimento de formas de representação dos trabalhadores constituídas com o objectivo da negociação colectiva. Esta democracia representativa traduziu a implantação, na empresa, de uma concepção elitista da democracia, tal como aquela que foi promovida por J. Schumpeter (Schumpeter, 1943). Todavia, esta abordagem foi objecto de críticas, perceptíveis, sobretudo, na esteira de 1968.

\section{Autogestão e alternativa}

Os movimentos conduzidos pelos operários especializados, misturando imigrantes e jovens assalariados muitas vezes distantes das estruturas que deviam representá-los, não se limitam às reivindicações salariais. Fora do sistema de relações profissionais rebentam revoltas que contestam a organização dita científica do trabalho e a sua dupla especialização: vertical, separando a concepção da execução das tarefas, e horizontal, dividindo o

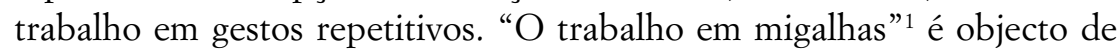
acusação e as exigências de participação formuladas pelos próprios assalariados são retomadas pelos sindicalistas e pelos políticos. É a irrupção da corrente autogestionária no campo intelectual. No dealbar dos anos 1960, o pensamento crítico era dominado por análises centradas nos dispositivos de controlo social. De imediato, a sensibilidade autogestionária deslocou-se para o terreno de acção. Para ela, em vez de se refinar a análise da alienação, era importante combatê-la o mais rapidamente possível.

\footnotetext{
${ }^{1}$ Segundo o título da obra de G. Friedmann.
} 
Segundo A. Mellucci, após a expropriação da revolução industrial, esta sensibilidade exprime a recusa de uma segunda expropriação cultural e simbólica, levada a cabo pelo capitalismo moderno. A contestação autogestionária ecoa os associacionismos pioneiros, na medida em que se demarca das representações concedidas ao movimento operário da sociedade industrial. Para além disso, estende-se da produção ao modelo de crescimento. Os movimentos anti-autoritários e ecológicos não estão centrados na repartição das riquezas e não abordam as relações sociais somente a partir da pertença a uma classe. Orientam-se no sentido de reivindicações mais qualitativas de direitos políticos de participação no poder, constituindo testemunhos de uma "sociedade pós-industrial", no dizer de D. Bell, e de um "pós-materialismo", nas palavras de R. Inglehart (apud Neveu, 1996: 66-74).

A singularidade dos novos movimentos sociais não é sinónimo, contudo, da sua unidade. A contestação da divisão social do trabalho e a exigência de uma participação acrescida alimentam dois projectos de transformação social: os "militantes políticos" distinguem-se dos "alternativos". Os militantes permanecem fiéis à prioridade atribuída à acção política. É certo que propõem o regresso às fontes do socialismo, constatando, através da crítica da burocracia, que a abolição da propriedade privada não é suficiente para realizar o projecto socialista. Porém, subordinam a adopção da autogestão à conquista do poder de Estado. Os alternativos, por sua vez, procuram constituir imediatamente espaços de autogestão limitados. Esta divisão entre militantes e alternativos pode ser ilustrada pelo movimento anti-nuclear, do qual uma parte se concentra na organização de grandes manifestações, enquanto a outra se esforça também por provar a viabilidade das energias renováveis. Esta vontade de mudar "aqui e agora", através da experimentação, explica que muitos deles se voltem para práticas económicas que, supostamente, abrem caminho a uma economia alternativa. ${ }^{3}$

Retomando a ligação com o messianismo comunitário, estes grupos estão convictos da exemplaridade do seu modo de vida na modificação das relações habituais entre consumo e produção. A legitimidade da sua atitude deve, para eles, ser suficiente para a respectiva difusão. Os rendimentos fracos e o tempo de trabalho são compensados pela boa parte que dedicam à polivalência, à igualdade das remunerações, às discussões e à informação recíproca. A taxa de insucesso das experiências destes grupos é elevada. A maior parte dos grupos que pratica um questionamento radical das noções

\footnotetext{
2 Retomando a terminologia de D. Mothé, 2005: 53-60.

${ }^{3}$ Cf. C. Gendron, 2004: 400-402.
} 
de trabalho e de emprego ${ }^{4}$ desaparece. O carácter maximalista dos objectivos revela-se inversamente proporcional à durabilidade das estruturas. Renunciando à perspectiva de uma economia alternativa, os promotores dos grupos que puderam ou quiseram subsistir visam, mais modestamente, a responsabilização dos seus membros no seio de unidades económicas geridas colectivamente, mas inseridas numa lógica de mercado. As empresas constituídas desta forma têm acesso, nalguns casos, a nichos de mercado, graças à inscrição prévia dos seus membros em redes políticas e sociais.

Distante do seu objectivo inicial, esta dinâmica alternativa está sobretudo na origem de novas formas de trabalho associadas ao terciário "pós-industrial" (Huber, 1981). Sob o seu impulso, em diversos países, o movimento cooperativo do trabalho abre-se à prestação de serviços intelectuais e culturais. Estas cooperativas representavam, nos serviços e em 1985, 45\% das cooperativas e 32\% dos postos de trabalho na Grã-Bretanha, 13,5\% das cooperativas no Quebeque, 18,1\% das cooperativas e 6,5\% dos postos de trabalho em França. No domínio da formação, da consultoria, dos estudos técnicos, dos media, das artes e do lazer, estes pequenos grupos de jovens qualificados, unidos frequentemente por uma prática de trabalho anterior numa empresa onde dominavam as relações com os clientes, contribuem para reforçar o número de criações de cooperativas e a baixar a dimensão média das mesmas.

Nascidas como "projectos imaginários de sociedades alternativas" (Desroche, 1976) com base numa ideologia "associacionista" que recuperava algumas das aspirações expressas no século anterior por Owen, Saint-Simon ou Fourier, as empresas alternativas tinham como objectivo antecipar, pelo seu próprio funcionamento, uma economia alternativa "que reunisse idealmente o que a sociedade contemporânea divide” (Vienney, 1980-1982). Rapidamente, estas empresas renunciaram ao seu projecto de mudança societal, ou abandonando a experiência económica ou inflectindo no sentido de um projecto de empresa inovadora, tendo preferido, então, o estatuto cooperativo como aquele que melhor se adaptava à formação e à gestão de empresas controladas por aqueles que ali trabalham. Assim, os empresários colectivos que estiveram na origem das cooperativas de trabalho prefiguram, desde a década de 1970, os processos de reabilitação de empresas que se afirmariam na década seguinte.

A sensibilidade autogestionária com múltiplas ramificações não conseguiu resistir a uma diluição progressiva. Alimentou-se de efervescência social depois da explosão de Maio de 1968. Porém, a contestação da monopoli-

${ }^{4}$ Autogestions, 1981. 
zação da informação por parte de alguns, da profissionalização e da especialização das funções sociais, bem como do formalismo das práticas de delegação, deixou de assentar numa base social activa. As dificuldades e as ambiguidades das experiências isoladas num ambiente desfavorável amplificaram-se, a mobilização diminuiu. Contudo, este enfraquecimento não deve ocultar a variedade de experiências a que deu lugar. Numerosas criações de empresas, adoptando, na sua maioria, o modelo cooperativo, estiveram ligadas ao questionamento dos modos de organização hierárquica. Outra característica desta dinâmica é a ligação estabelecida entre os objectivos da produção e os meios utilizados para os atingir. Enquanto que, no movimento cooperativo anterior, esta questão não tinha sido tida em conta, nesta nova vaga de cooperativas, o modo de organização interno foi considerado como uma garantia da utilidade social e ambiental da produção. A questão dos objectivos da actividade articula-se com a questão do seu funcionamento.

Por esta razão, é possível designar estes colectivos como "colectivos de intervenção", 5 uma vez que preconizavam relações de trabalho diferentes e fixavam, para si mesmos, um horizonte de mudança que ia para além dos seus próprios limites como entidade económica. Não se centravam unicamente sobre o seu próprio funcionamento interno, mas visavam uma acção mais ampla sobre a sociedade, postulando uma ligação entre auto-organização do trabalho e democratização da sociedade. No início, desejavam praticar formas de democracia directa e de não se satisfazer com as modalidades da democracia representativa incluídas no estatuto cooperativo. Para além disso, dada a natureza dos bens e serviços que propunham, queriam também trabalhar no sentido da preservação do ambiente ou da redução das desigualdades. É o caso dos gabinetes de estudos dedicados às novas energias, ou das lojas que distribuem produtos biológicos. É também o caso das associações de investigação, dos gabinetes de juristas ou de gestão, das cooperativas de consultoria ou de formação, cujo objectivo é colocar os saberes geralmente reservados aos especialistas à disposição do maior número de pessoas, de modo a lutar contra os "abusos de saber" que M. De Certeau refere (De Certeau, 1980). Mesmo se não desenharam os contornos de uma economia alternativa, os colectivos de intervenção abriram brechas. Legam questionamentos que irão ser recobertos pela vaga

\footnotetext{
${ }^{5}$ Esta expressão foi proposta para referir que, em relação à intervenção sociológica teorizada por A. Touraine, é menos o confronto entre o grupo mobilizado e os sociólogos que explicita o sentido da acção do que os debates realizados no seio do próprio grupo, tendo em conta que este grupo de intervenção pode, ele próprio, fazer valer o direito de iniciativa e de expressão em favor de populações privadas do acesso ao espaço público. Ver O. Corpet, 1982; O. Corpet, M. Hersent, J. L. Laville, 1986.
} 
neoliberal da década de 1980, mas, apesar de tudo, terão influência sobre as iniciativas que reencontraremos mais tarde, híbridos da inspiração autogestionária e da luta contra o empobrecimento.

\section{As aquisições de empresas}

Os colectivos voluntários que acabámos de descrever estavam ligados à crise de valores que afectou o modelo de crescimento dos Trinta Gloriosos. A partir da década de 1980, a conjuntura económica altera-se: são os colectivos forçados, resultantes da crise económica, que passam a desempenhar o papel mais importante. Ao contrário do que acontecia na época do pleno emprego e do trabalho em migalhas, uma parte do trabalho industrial passou a ter como característica solicitar a especialização cognitiva e a inteligência, o que explica a adopção da gestão participativa, prolongando as teses de autogestão ao serviço da empresa. Simultaneamente, o livre-câmbio e o fim das restrições sobre o mercado de capitais tornam possível a deslocalização das produções para países com salários baixos e sem protecção social. Os assalariados das multinacionais são, simultaneamente, intimados a envolver-se na produção e submetidos à ameaça da perda do emprego. Esta injunção paradoxal é associada a uma defesa da substituição da regulação pública, considerada demasiado restritiva, por uma regulação ética resultante do voluntariado das empresas. Exerce-se pressão no sentido da baixa dos salários e da redução das despesas sociais.

Com a "corporate governance", as normas de rentabilidade definidas pelos accionistas livres para escolher os seus investimentos no mercado internacional, entre 12 e $15 \%$ do capital, transformam o trabalho em variável de ajustamento. Daqui resulta a multiplicação das tentativas de conversão de empresas em cooperativas para salvar as produções consideradas pelos assalariados como viáveis, mesmo que estas não satisfaçam as exigências do mercado internacional de capitais.

Depois da renovação enraizada na ideologia alternativa, o movimento cooperativo de trabalho foi profundamente afectado por uma outra vaga de cooperativas, fruto já não de uma escolha, mas de uma necessidade: as aquisições de empresas. Em Itália, apesar da falta de rigor das estatísticas, pode falar-se de cerca de 1.000 aquisições, de 1975 a 1985, a maioria no Norte do país, na área do têxtil e do vestuário, da tipografia, da mecânica de pequena dimensão, da madeira e do transporte, empregando em média entre 30 e 100 assalariados. Em Espanha, as aquisições foram feitas não somente sob a forma de cooperativa, mas também sob a forma de sociedades anónimas de trabalhadores com uma participação dos empregados no capital maioritário. O número não é conhecido em termos exactos, mas 
corresponde a, no mínimo, mil e trezentas empresas e 50.000 postos de trabalho. Em França, entre 1978 e 1983, um período de expansão desigual desta dinâmica, as aquisições representaram entre 37 e $61 \%$, dependendo dos anos, do conjunto dos novos postos de trabalho cooperativos. São os países mais marcados por este fenómeno. No Reino Unido e na Alemanha, ou na Dinamarca, as aquisições têm uma importância bem menor: em 1986, o seu número em cada um destes países é, respectivamente, 90, 13 e 14.

Dado aquilo em que se tornaram as normas de rendimento no mercado internacional de capitais, existe uma variedade de circunstâncias nas quais uma empresa pode, apesar de tudo, ser rentável, sem atrair investidores privados. Os empregados vêem-se, então, confrontados com a necessidade de reorganizar e de fazer funcionar as actividades "perturbadas", acrescentando, por vezes, projectos de reconversão industrial. As aquisições são, por conseguinte, uma reacção lógica a escolhas mais selectivas por parte dos detentores de capitais, mas sofrem de uma má "imagem de marca", explicável pela mediatização extrema e pela politização de alguns casos. Estes casos $^{6}$ correspondem, na maior parte, a empresas de mais de 100 empregados, com uma forte delegação de poder dos assalariados nos sindicatos, e desviaram a atenção das aquisições bem sucedidas que dizem respeito a empresas mais pequenas em sectores de forte qualificação do pessoal e de fraca intensidade capitalística, nos quais a performance está ligada à qualidade do trabalho. São as empresas nas quais foram os assalariados aqueles que estiveram mais directamente envolvidos na decisão da aquisição, uma decisão que não foi tomada unicamente pelos respectivos líderes sindicais, mesmo quando estes conseguiram tornar-se gestores dessas empresas. Para não referir mais do que um exemplo: em França, das aquisições em modelo cooperativo efectuadas em 1981, 63\% estavam ainda em actividade cinco anos mais tarde, ou seja, uma percentagem melhor do que o conjunto das pequenas e médias empresas, das quais mais de metade desaparece durante os três primeiros anos. Todavia, as aquisições continuam a ser sinónimos de fracasso, pois a opinião pública ficou marcada por falências retumbantes como a da Manufrance.

Em nenhum país, com excepção da Itália, onde a força anterior pode explicar este fenómeno, o movimento cooperativo foi capaz de construir um sector industrial a partir das aquisições. As tentativas da parte do Estado ou dos sindicatos de instrumentalizar a cooperativa de trabalho como meio

\footnotetext{
${ }^{6}$ Entre os mais conhecidos: The Scottish Daily News, KME e Méridien na Grã-Bretanha (chamados as cooperativas "Benn" devido ao apoio do ministro trabalhista Benn), Clems na Itália, Tricofil no Québec.
} 
de salvaguardar o emprego a grande escala mudaram repentinamente, quer em França com a união da esquerda, quer em Inglaterra durante o mandato do ministro Benn. Apesar de tudo, depois de levantados estes obstáculos, as relações entre entidades públicas, sindicatos e cooperativas foram objecto de acordos menos voluntaristas e mais circunstanciados.

Alguns foram introduzidos a nível nacional, como as alterações nos regulamentos da segurança social e o seguro de desemprego destinados a encorajar a criação de empresas pelos desempregados: por exemplo, o "Entreprise allowance scheme" no Reino Unido e os programas para os desempregados criadores de empresas, cujas modalidades criam vantagens para as aquisições de empresas, em França e em Espanha. Os governos locais e regionais também tenderam a aumentar as suas intervenções na economia para apoiar as actividades nos territórios respectivos. Assim, no Reino Unido, em 1986, cerca de 80 organizações de apoio às cooperativas recebiam apoios de governos locais, particularmente de autoridades trabalhistas. Em França, a descentralização facilitou a intervenção económica das colectividades territoriais.

Por fim, certos sindicatos chegaram ao ponto de redefinir as suas relações com o movimento cooperativo. Em Itália, o número de aquisições que se consolidaram deve-se também ao facto de os principais sindicatos, já associados às diferentes federações cooperativas, segundo as respectivas sensibilidades políticas, terem ido mais longe no seu empenhamento, assinando, em 1985, um acordo com as federações cooperativas sobre a natureza e o volume de apoio público necessário às cooperativas e sobre os esforços comuns a realizar para atingir esse objectivo. No Quebeque, a Central dos Sindicatos Nacionais criou, em 1986, um grupo consultivo para fornecer apoio no domínio da gestão aos projectos de cooperativas, bem como para facilitar "a passagem de uma democracia formal a uma gestão participativa das operações quotidianas”. Porém, na maior parte dos países, os apoios sindicais desenvolvem-se numa semi-clandestinidade ao nível local. Contrastam, assim, com o fracasso das políticas anteriores de apoio centralizado que beneficiavam de fortes efeitos de divulgação.

Não é só a Europa que regista aquisições de empresas. Os países sul-americanos afectados pelos encerramentos de estabelecimentos no quadro das reorientações estratégicas das multinacionais constituem a sede das "empresas recuperadas", como se diz na Argentina, um dos países onde o fenómeno é mais massivo. Estas empresas recuperadas pretendem ser um instrumento para, simultaneamente, criar emprego e revitalizar a participação operária. Enquanto, na Europa, estas aquisições surgiram mais na sequência da autogestão como palavra de ordem, na América do Sul, são 
indissociáveis de uma reminiscência da iniciativa autogestionária. Apesar disso, encontramos nelas as mesmas dificuldades que acabámos de descrever relativamente às aquisições europeias. A despeito de alguns sucessos económicos, o entusiasmo inicial foi temperado pela subcapitalização e pela obsolescência tecnológica de que muitas delas padecem, nas indústrias tradicionais como o têxtil ou o calçado.

\section{A redescoberta da economia popular}

Estas aquisições realizadas em nome da autogestão, num momento em que esta temática já tinha sido abandonada no debate europeu, inscrevem-se numa dinâmica de reactualização da economia popular bastante mais ampla. Apesar das esperanças que nelas eram colocadas, as esferas do Estado e do mercado orientado para a exportação jamais permitiram uma integração salarial tão forte como no Norte; havia sectores inteiros da população privados do acesso aos circuitos formais de emprego. Na América do Sul, de 1925 a 1950, a população urbana crescera $12 \%$ e o emprego não agrícola 87\%. Pelo contrário, de 1950 a 1960, a criação de empregos não agrícolas foi inferior ao crescimento da população urbana: as percentagens respectivas são de $59 \%$ e de $46 \%$, atingindo $47 \%$ e $40 \%$ de 1960 a 1970 . Com as ditaduras e os regimes autoritários que interromperam os espaços de democracia experimentados nas décadas de 1950 e 1960, com a crise da dívida e a desregulamentação social que se seguiram, atinge-se metade da população activa excluída da economia formal num país como o Brasil. Novamente, esta população sobrevive graças a formas de solidariedade imersas nas redes comunitárias. A economia informal serve de refúgio a $35 \%$ da população activa, segundo as estimativas para a América Latina. Neste conjunto heterogéneo, muitas são actividades comerciais sem defesa para aqueles que as exercem, ligadas às estratégias de externalização das empresas capitalistas, algumas ilícitas e acompanhadas de violência extrema. Porém, há uma outra parte que constitui uma resposta popular a uma situação económica difícil. Como acontecera perto de dois séculos mais cedo, o crescimento de formas mais associativas corresponde a uma afirmação da solidariedade no prolongamento das cooperações habituais vividas no interior dos grupos primários. O modo de organização do trabalho assente na mobilização colectiva e a gestão democrática dos projectos estão indissociavelmente ligados à resolução de problemas de sobrevivência.

Baseadas na ajuda mútua e na propriedade comum dos meios de produção, estas associações populares incluem oficinas de produção ${ }^{7}$; organizações

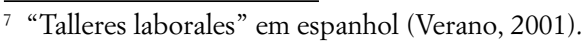


de desempregados que procuram emprego colectivamente; grupos de alimentação comunitária, como, por exemplo, as cozinhas colectivas e as hortas; organizações dedicadas aos problemas de habitação, de electricidade e de água potável; organizações pré-cooperativas de auto-construção; associações de prestação de serviços à colectividade nos domínios da saúde e da cultura. A observação destas organizações durante dez anos em Santiago do Chile, onde $25 \%$ da força de trabalho evolui no seio da economia popular, atesta a queda dos grupos de alimentação (de $54 \%$ a $9 \%$ das organizações económicas populares), o crescimento das oficinas de produção (de $53 \%$ a $68 \%$ ) e o desenvolvimento da satisfação de outras necessidades que vão para além da sobrevivência (habitação, saúde, educação,...), bem como uma integração horizontal e vertical para diminuir o isolamento das associações. Os estudos realizados em todo o Chile revelam que a economia popular envolve perto de metade da população activa e que $70 \%$ dos trabalhadores não deseja mudar, o que traduz a ligação a um modo de vida. Estas iniciativas estão presentes tanto no Chile, como na Argentina, no Brasil, na Colômbia, no Equador, no México, no Peru ou no Uruguai. Apoiam-se nos movimentos negros e indígenas (Alvarez et al., 1998: 333), como acontece nos países dos Andes, onde os princípios da organização índia são reactivados para gerar modelos de desenvolvimento originais, como o projecto Nasa na Colômbia, premiado pelas Nações Unidas. Neste país, como noutros, um dos exemplos mais ilustrativos é o das cooperativas de reciclagem de resíduos. Na Colômbia, há cerca de 300.000 pessoas, ou seja $1 \%$ da população, a viver da recolha, das quais 50.000 em Bogotá. Estas pessoas são vítimas, simultaneamente, dos intermediários formais e informais aos quais revendem, bem como de um desprezo social que os assimila ao lixo que recolhem na rua. A criação de cooperativas, desde 1987, resulta, por conseguinte, de uma reacção contra este ostracismo. Tem como objectivo lutar contra a dispersão e a concorrência frontal face aos intermediários, através de uma organização económica que lhes confira uma relação de forças menos desfavorável. Para além disso, estas cooperativas pretendem também combater a exclusão, através de uma organização social, política e cultural que dê acesso a direitos. Esta dinâmica conduziu a um agrupamento, em 1990, na Associação dos Recicladores de Bogotá, a nível regional com a Associação da Costa Norte e, em 1991, a nível nacional, com a Associação Nacional dos Recicladores, que reúne 88 das 94 cooperativas, representando $10 \%$ da população que vive da recolha.

Um outro exemplo emblemático é o do Movimento dos Sem Terra (MST) no Brasil, nascido em 1984. Em 2000, foram 250.000 as famílias que se reapropriaram das terras não ocupadas que permaneciam improdu- 
tivas. Cerca de 50 cooperativas de produção agrícola e pecuária agrupam 2.300 famílias, cerca de 30 cooperativas de serviços beneficiam 12.000 famílias. Paralelamente ao "Sistema de Cooperativismo dos Assentados", há centenas de associações de produtores que funcionam como instâncias através das quais se pode receber créditos. Existem 1.800 escolas do ensino básico com 3.800 professores e 150.000 alunos, 1.200 educadores de jovens e 250 creches.

Estes dois exemplos têm sido alvo de avaliações diferenciadas. No que diz respeito às cooperativas de reciclagem na Colômbia, o estatuto de empregado adquirido pelos trabalhadores, com um uniforme, segurança social, seguros, bem como a integração num colectivo, têm efeitos de melhoramento dos quadros de vida e de trabalho, ajudam a sair de um verdadeiro apartheid social. Porém, o percurso das cooperativas revela todas as dificuldades: o individualismo tradicional do meio, as delimitações das responsabilidades com as organizações não governamentais, cujo apoio é indispensável, mas cuja intervenção pode ser percebida como uma ingerência por parte dos associados, o confronto com um processo de privatização e de racionalização da recolha que oferece oportunidades e, ao mesmo tempo, corre o risco de beneficiar as empresas de dimensão superior, a necessidade de alianças com o sector privado que daqui resulta, com os riscos de absorção que lhe estão ligados. Como afirmou um gerente da Rescatar, uma das principais cooperativas, num encontro nacional: "A economia é global e universal. As mesmas privatizações que conhecemos na Colômbia também se fazem na Venezuela, no Equador, no Peru. Estamos no século XXI e continuamos a trabalhar como em 1900. Temos cem anos de atraso! Competimos em condições desiguais, com as nossas carroças, ao passo que as empresas de limpeza possuem veículos americanos e europeus de duzentos milhões de pesos. Desta maneira, não podemos ser concorrenciais. Temos de aprender a desenvolver projectos". 8

O MST é, por sua vez, alvo de polémicas. Estas devem-se ao seu sincretismo, no qual o entusiasmo pela reforma agrária e "a sociedade sem classes" influenciada pela teologia da libertação e pela revolução castrista segue lado a lado com o apego aos valores tradicionais da terra, da família e da religião. O MST provoca tanto o fascínio como a desconfiança face ao "encantamento" ideológico e à "canonização" da acção colectiva. A mobilização incontestável que concretiza e que amplifica através do seu papel motor na "Via Campesina" é questionada do ponto de vista do controlo centralizado dos seus debates internos. Z. Navarro evoca uma "mobilização sem eman-

${ }_{8 \text { Citado por C. Rodriguez, }} 2002$. 
cipação" do poder pelo controlo dos meios financeiros e o desdém relativamente à democracia - ao que $\mathrm{H}$. Martins de Carvalho retorque que o MST é um movimento em construção, tendo menos as características de uma organização social de massa do que as de uma rede entre classes campesinas marginalizadas da América Latina. Para Martins de Carvalho, as práticas actuais explicam-se pela descoberta de novos códigos culturais, através de fluxos de informação e de símbolos que, apesar dos erros, forjam uma identidade social autónoma. ${ }^{9}$ Segundo este autor, a emancipação é real para muitos dos actores de movimentos anteriormente analfabetos e agora implicados num processo de educação popular.

A nova vaga de economia popular tem sido, por conseguinte, objecto de análises controversas. Um ponto de referência é a contribuição de Razeto, que coloca o acento na consolidação e na democratização destas práticas económicas, ancoradas num tecido comunitário, mas procedendo à recomposição desse mesmo tecido. A. Quijano (Quijano, 1998) é menos optimista: considera que o individualismo está a impor-se nas organizações económicas populares e que a necessidade determina mais a acção do que a solidariedade. Para este autor, existe realmente uma combinação, no seio daquelas organizações, entre as lógicas do capital e da reciprocidade, o que constitui uma especificidade inegável, mas insuficiente. A dependência destas organizações é demasiado marcada para se poder falar, como faz Coraggio, de uma economia do trabalho que se oporia à economia do capital.

A diversidade das interpretações prova, em todo o caso, que a economia popular deixou de ser entendida como um fenómeno arcaico ou transitório, destinado ao desaparecimento, segundo "a lei de bronze" do desenvolvimento capitalista. O reconhecimento da existência de um saber popular em economia torna-se inegável a partir do momento em que há investigações consagradas à compreensão da racionalidade interna das iniciativas. Mesmo que estas iniciativas não tenham conseguido sair completamente de uma condição marginal, deixaram de se limitar unicamente a gerir a miséria. Contudo, é igualmente verdade que estão ainda abertas muitas questões sobre as capacidades desta economia no sentido de ultrapassar o simples plano da reprodução das condições de vida para alcançar o plano de uma reprodução alargada, ou no sentido de passar de um nível de sobrevivência e de subsistência a determinadas formas de acumulação. A economia popular é atravessada por uma tensão entre eficiência técnica e dinâmica solidária, entre educação dos participantes, dos quais muitos são analfabetos, e respeito dos valores iniciais que explicam o empenhamento destes.

\footnotetext{
${ }_{9}$ Ver o debate entre os dois: Z. Navarro, 2002: 189-232 e H. Martins de Carvalho, 2002: 233-260.
} 
Em todo o caso, relativamente a uma perspectiva que a confundia com a economia informal, o ponto de vista dos observadores alterou-se: hoje em dia, os fundamentos da economia popular merecem atenção. Este interesse recente resulta de uma legitimação e induz uma pressão exercida sobre os poderes públicos no sentido de conferirem direitos plenos a esta economia. Neste contexto, há já organizações não governamentais sensibilizadas para este tema e activas, e foram já constituídas redes universitárias em vários países, como o Peru, o México, a Argentina, a Colômbia, o Uruguai. Porém, é o Brasil que mostra melhor os avanços neste domínio. Desde 1980, a "Caritas" financiava milhares de "projectos alternativos comunitários", em 1999, a "Central Única dos Trabalhadores" (CUT) começou a empenhar-se fortemente, através da sua Agência de Desenvolvimento Solidário (ADS): dedicada à formação e à divulgação de informação, destinadas tanto aos militantes sindicais como às cooperativas, esta agência foi criada em parceria com a "Unitrabalho" que associa mais de 80 universidades. Esta fundação está igualmente na origem das Incubadoras Tecnológicas de Cooperativas Populares (ITCP) que ajudam no arranque das cooperativas e dos grupos de produção associados.

A economia popular encontra assim, nas últimas décadas, uma visibilidade que havia perdido. Se permanecem ténues os laços entre as empresas "autogeridas" que resultam de falências industriais e as novas cooperativas na área dos serviços (limpeza, reciclagem, produção artística, formação,...), grupos variados provenientes de igrejas, de sindicatos e de universidades propõem actualmente apoio e ajudam a economia popular em articulação com diversos movimentos de emancipação e da defesa de direitos, como, por exemplo, organizações ecologistas.

Nestas excrescências da economia popular está em jogo, de facto, uma acentuação da sua dimensão pública. Segundo A. O. Hirschman (Hirschman, 1971), nas iniciativas económicas populares da América Latina, a luta pela melhoria das condições de vida dos membros dos sectores populares está intrinsecamente ligada ao combate pelos direitos de cidadania. Esta luta oscila entre a reivindicação e a auto-resolução dos problemas, sem separar as questões materiais das questões relativas às condições de vida e de convivialidade. Como afirma M. Scholnik: "é uma maneira diferente de fazer política” (Scholnik, 1984: 28). É o mesmo que defendem os grupos de mulheres que se insurgem contra o escândalo da oposição gerada entre público e privado, entre produção e reprodução. Esta oposição atribui às mulheres actividades não remuneradas que perfazem dois terços do respectivo tempo de trabalho, enquanto dois terços do tempo de trabalho dos homens é remunerado. Historicamente, o confinamento das mulheres a 
uma economia doméstica ignorada explica a sua subrepresentação física e simbólica nos espaços públicos. Se as mulheres são maioritárias nas iniciativas populares, é justamente porque elas consideram que estas iniciativas colectivas são susceptíveis de identificar e contextualizar as necessidades, para depois as exprimir e levar à esfera pública. Face ao fracasso das medidas estandardizadas e universalistas, as iniciativas são um meio de concretizar os direitos e de os traduzir em capacidades de acção, graças a um colectivo que constitui um recurso para desenvolverem a confiança em si mesmas, aliviar o peso das responsabilidades assumidas na esfera familiar e conciliá-las com um empenhamento ao serviço da justiça social. Estas acções colectivas pretendem ser, em primeiro lugar, respostas pragmáticas a problemas da vida quotidiana. Todavia, também formulam reivindicações societais e ambientais, estabelecendo uma ligação com o feminismo ecológico que se insurge contra uma concepção materialista e economicista da riqueza que assimila os saberes domésticos a qualidades "inatas", a um "altruísmo" e a "obrigações" femininas.

\section{Algumas iniciativas locais e internacionais}

As experiências do Sul no âmbito da economia popular impulsionam uma alteração do modo como são encaradas as actividades de proximidade que implicam cuidados e atenção aos outros, do qual faz parte a partilha mais igual destas tarefas e uma tomada de consciência relativamente às riquezas que elas geram. Neste plano, elas revelam-se muito próximas de actividades realizadas no Norte sob a designação de serviços de proximidade.

\section{Os serviços de proximidade}

Nos países escandinavos, há organizações novas que revelam uma forma de agir diferente da das associações tradicionais. Desviando-se da abordagem política e cultural hegemónica na década de 1970, estas organizações propõem, nos anos 1980, "novas formas organizacionais e soluções para os problemas sociais locais” (Klausen e Selle, 1996: 99-122). Entre elas figuram as organizações denominadas "promotoras de projectos", na Dinamarca, apoiadas pelos poderes públicos com o objectivo de reforçar a assunção de responsabilidades por parte de cidadãos voluntários nas políticas sociais. Na Suécia, as organizações de mulheres criaram centros de acolhimento e de aconselhamento para as mulheres vítimas de violência doméstica, levando mais de metade dos municípios a realizar iniciativas públicas de apoio às mulheres. Na mesma década de 1980, pais e mães iniciaram modalidades de guarda de crianças, porque, na sua perspectiva, o serviço público não correspondia a todas as necessidades, nem quantitativa, nem 
qualitativamente, dada a estandardização do funcionamento das creches. O governo social-democrata concedeu o direito às cooperativas de guarda de crianças a serem financiadas a $85 \%$ com fundos públicos. Mais tarde, em 1991, foram levantadas todas as restrições quanto ao estatuto jurídico da oferta neste domínio. $15 \%$ das crianças que não estão ainda em idade de escolarização são acolhidas em creches não municipais, das quais a maioria são cooperativas de pais e mães. Outras são cooperativas de trabalho ou associações (Pestoff, 1998, 2004). A forma cooperativa e associativa participa, neste contexto, tanto na reorganização dos serviços existentes como na criação de novos serviços. A “cooperatização" (Lorendahl, 1997) dos serviços sociais responde, antes de mais, a um objectivo de aumento do papel dos utilizadores, como é o caso dos pais e mães na organização da guarda das crianças, e foi aceite sob a pressão dos constrangimentos financeiros que se exercem sobre o sector público.

No Reino Unido, na década de 1990, as associações de pessoas portadoras de deficiência, bem como aquelas que representavam minorias culturais, desenvolveram, contra aquilo que os respectivos porta-vozes denominaram o paternalismo das autoridades e a cegueira do mercado, abordagens radicais incentivando a participação dos utilizadores na elaboração dos serviços que lhes são destinados. No desenvolvimento local, as abordagens "comunitárias" que provêm dos habitantes tiveram expressão, por exemplo, através do desenvolvimento da "community transport association", reconhecida ao nível nacional como órgão representativo de grupos que se aproximaram para compensar a falta de transporte adaptado às suas necessidades, do desenvolvimento das "community enterprises" numerosas na Escócia, das "community foundations" e dos "community development trusts". Todas estas iniciativas tiveram lugar em territórios rurais e urbanos onde a economia de mercado declina. Pretendem insuflar, nesses mesmos territórios, uma nova dinâmica proveniente da própria população. Na protecção do ambiente, os "Groundwork trusts" conduzem muito mais de 3.000 projectos, cuja característica comum é a participação dos habitantes na respectiva concepção e concretização, e na parceria com associações ecologistas, colectividades locais e empresas. Na guarda de crianças, os "playgroups" são sítios de acolhimento a tempo parcial para as crianças pequenas. Dirigidos pelos pais como reacção à deficiência da oferta, eram 18.000 em 1998 e forneciam 19\% das vagas disponíveis para crianças de menos de 5 anos (Taylor, 2004).

$\mathrm{Na}$ Alemanha e na Áustria, as iniciativas são designadas de "entreajuda" para traduzir a vontade de responsabilização das pessoas que as dinamizaram. Podem dividir-se em três subsectores: grupos semi-informais, grupos 
de "auto-assistência", isto é, que reúnem pessoas afectadas pelo mesmo problema, e grupos que defendem a causa de certas populações, das quais eles próprios não fazem parte. Constituem-se na base do voluntariado e o trabalho profissional remunerado intervém apenas como complemento. Há 70.000 iniciativas destas na Alemanha, com aproximativamente 2,65 milhões de pessoas envolvidas (Evers et al., 1999). A partir da década de 1980, registam-se fusões, sobretudo nos domínios da saúde e da acção social, havendo entre 5.000 e 10.000 grupos somente na área da saúde. Estas organizações enraízam-se numa crítica da burocratização dos serviços públicos e das grandes organizações de beneficência. Daqui resultam novas organizações locais: em Viena, por exemplo, a guarda de 65.000 crianças é assegurada metade pelo serviço público e metade por associações quer tradicionais, quer resultantes destas iniciativas ditas "de base" (Leichsenring, 1997).

Como na França e na Bélgica, trata-se de renovar as formas de oferta associativa, reconhecendo que a ausência de fins lucrativos não garante, só por si, o respeito pelos utilizadores. Neste contexto, as associações, que durante muito tempo foram as principais prestadoras de serviços, beneficiaram de quasi-monopólios locais. Com a tendência para a abertura concorrencial, muitas delas tentam melhorar as respectivas performances, seguindo formas de gestão empresariais, nomeadamente através da adopção de instrumentos de marketing. Porém, ao passo que esta uniformização produz resultados fracos, ${ }^{10}$ outras associações esforçam-se por encontrar uma especificidade e regista-se igualmente iniciativas que emergem em torno de uma abordagem que não confunde utilizador com consumidor. Estas inovações, quer adoptem a via da renovação de associações antigas ou a via da criação de novas associações, definem como desafio central a prática de funcionamentos associativos originais. Segundo os seus promotores, é da capacidade das organizações de suscitar a expressão dos utilizadores, no sentido da tomada da palavra de Hirchsman (Pestoff, 1998), bem como de mobilizar envolvimentos voluntários diversificados e de encontrar novos equilíbrios financeiros apropriados num contexto menos protegido; é desta capacidade que depende, a longo prazo, a legitimidade da oferta associativa de serviços. Em França, os estabelecimentos de guarda de crianças com participação parental constituem um exemplo destas inovações. Reconhecidos em 1981, desenvolveram-se amplamente, depois de terem surgido sob a forma de creches selvagens, em ruptura com a medicalização, com a separação e com a especialização tradicionais dos modos colectivos de

\footnotetext{
${ }^{10}$ Para uma demonstração dos efeitos perversos da profissionalização gestionária das associações, ver a introdução de J. L. Laville, R. Sainsaulieu, 1997.
} 
guarda de crianças. Duas tendências marcam a sua evolução. A primeira é o alargamento das categorias de iniciadores: muitos estabelecimentos resultam da iniciativa de profissionais que querem criar o seu próprio emprego, ou são iniciativa de instituições ou colectividades locais. A segunda é o alargamento do público visado. Originariamente urbano, e mesmo parisiense, o movimento das creches parentais difundiu-se devido à facilidade de adaptação. Diversificou-se, integrando funções de acolhimento a tempo parcial, sem necessitar de investimentos exorbitantes e apresentando um custo em média um terço inferior às restantes estruturas colectivas.

A amplitude do fenómeno dos serviços de proximidade pode parecer modesta. Não obstante, começou a ser reconhecido a nível nacional nas políticas sociais e económicas experimentais, como o programa "empregos-jovens" em França. A nível europeu, o "Livro branco", documento de reflexão da Comunidade Europeia para o século XXI, é o primeiro a fazer-lhe referência, anunciando "um número de três milhões de novos empregos" que poderiam ser repartidos "igualmente entre os serviços de proximidade, o melhoramento das condições de vida e a protecção do ambiente" (Commission Européenne, 1993: 13). Os inquéritos realizados pelos serviços da Comissão precisam, de seguida, os domínios de actividade daquilo que é designado por serviços de proximidade nos países francófonos e que é denominado iniciativas locais de desenvolvimento e de emprego, segundo uma terminologia mais consensual no conjunto da União Europeia (Jouen, 1995). Quatro grandes campos são enumerados (Commission Européenne, 1995, 1996): os serviços da via quotidiana, com os serviços domiciliários, a guarda de crianças, as novas tecnologias da informação e da comunicação; os serviços de melhoramento das condições de vida com a habitação, a segurança, os transportes colectivos locais, a revalorização dos espaços públicos urbanos, o comércio de proximidade, a valorização do património cultural, o desenvolvimento cultural, local, o desporto; os serviços do ambiente com a gestão de resíduos, a gestão da água, a protecção e manutenção das zonas naturais, a regulamentação, o controlo da poluição e as instalações correspondentes. ${ }^{11}$

Nascidos em torno da recomposição dos serviços sociais, os serviços de proximidade não puderam esquivar-se ao facto de uma das principais causas do crescimento das desigualdades ser o aumento do desemprego e da exclusão. Então, foram desenvolvidos serviços de inserção pela actividade económica, cujo objectivo principal é a integração no emprego de pessoas em dificuldade. Neste âmbito, a escolha de actividade faz-se em função da

${ }_{11}$ Para uma síntese das iniciativas locais na Europa, cf. L. Gardin, J. L. Laville, 2000; L. Gardin, 2006. 
sua capacidade de favorecer o acesso ao trabalho assalariado. A maior dificuldade dos serviços criados em torno da inserção é promover esta opção sem participar na extensão de estatutos derrogatórios ao direito comum que acentuam a degradação do assalariado pela instauração de um segundo mercado de trabalho. Pioneiras das políticas activas sobre os mercados do trabalho, combinando acompanhamento social e procura de eficiência económica, as iniciativas de inserção pelo económico oscilam entre uma simples função de "SAS" (Sociedade por Acções Simplificada) no sentido da economia de mercado e uma vontade de associar as pessoas acolhidas na gestão da entidade produtiva. O objectivo prosseguido ou é uma simples prestação de inserção, limitando-se a formar, em situação de trabalho, futuros assalariados de empresas privadas, e a ensinar-lhes regras de disciplina; ou é, mais amplamente, inclui-los como sujeitos de pleno direito e actores económicos. ${ }^{12}$

Se todas estas experiências se podem agrupar, é porque propõem uma nova modalidade de concepção dos serviços às pessoas. Os serviços elaborados desta maneira podem ser denominados serviços de proximidade, se adoptarmos uma acepção da proximidade na qual esta noção não remete apenas para uma objectivação de critérios de espaço ou de tempo, mas para a subjectividade dos actores. Evidentemente, a proximidade pode tomar a forma da vizinhança, porque, na maioria dos casos, dá lugar a serviços efectuados num território restrito, respondendo rapidamente à procura dos utilizadores. Contudo, esta proximidade não se confunde de forma nenhuma com o conceito de vizinhança. A proximidade define-se pelo facto de ser sentida, experimentada, interiorizada pelos actores. Em vez de cada um tentar resolver individualmente e na esfera privada os problemas quotidianos, com os quais é confrontado, os serviços de proximidade propõem tratá-los através da abertura da esfera privada à esfera pública. No início, não há mais do que algumas pessoas que começam a abordar entre elas questões das quais não falavam anteriormente. É quando a discussão passa a incluir estas realidades multiformes que a procura e a oferta se podem ajustar.

Por todas estas razões, apesar das diferenças de contexto, um certo número de elementos constitutivos da economia popular que foram descritos mais acima para as sociedades do Sul estão igualmente presentes nos serviços de proximidade. Se não limitarmos as necessidades às necessidades materiais, são elementos fundamentais no processo de formação e de reprodução de

${ }^{12}$ Uma síntese, a partir do caso francês, sobre os paradoxos da inserção: B. Eme, 2005; uma revista internacional das iniciativas: J. Defourny, L. Favreau, J. L. Laville, 1997; M. Nyssens, 2006. A diversidade dos perfis das iniciativas de inserção na Europa é detalhada, com menção de diferentes cenários. 
uma sociedade humana que estão em causa. É certo que não se trata de subsistência, mas antes de igualdade de acesso e de respeito dos direitos humanos nos serviços. Porém, é, de facto, um sentimento de pertença que desencadeia o envolvimento, mesmo se não está em causa uma identidade herdada, e sim uma identidade construída através da acção colectiva. É a igualdade dos membros que constitui a regra, mesmo que as experiências se encontrem menos ligadas a um tipo de actores do que a uma deliberação entre diversos tipos de actores (utilizadores, assalariados, voluntários,...).

A forte convergência entre a economia popular contemporânea no Sul e os serviços de proximidade no Norte tem a ver com a valorização dos saberes ligados à prestação de cuidados. Nos serviços de proximidade podemos também encontrar uma desconstrução da clivagem entre privado e público que não corresponde às vivências das mulheres e negligencia as competências de educação e de mediação que o trabalho afectivo reclama para contribuir para o bem-estar das crianças, das pessoas dependentes ou doentes (Folbre, 1997). ${ }^{13}$ Como no Sul, importa, em primeiro lugar, recordar que esta produção de cuidados era tradicionalmente assegurada pela família e, nesta, pelas mulheres. Contra uma divisão sexuada das tarefas, como esta, importa, de seguida, defender que estas actividades são cruciais e fundam o sentido da vida em sociedade. Ao contrário de uma dissociação e de uma hierarquização entre espaços económico, político e doméstico, instalando os homens no centro dos dois primeiros, para remeter as mulheres ao terceiro, como um enclave, adoptar a perspectiva da vida decente e do bem-estar humano leva a constatar que "é impossível não cuidar e não trabalhar" (Lewis, 2003). Os cuidados não podem, por isso, ser objecto de uma externalização total em favor do Estado ou do mercado, que não teria em conta a transmissão intergeracional que eles representam e que os instrumentalizaria em nome da criação de empregos, sem avaliar o respectivo substrato antropológico. Os cuidados constituem um bem público e assegurá-los pressupõe, por um lado, uma partilha das responsabilidades entre a família, as autoridades públicas, mas também o mercado e a sociedade civil; e, por outro lado, uma partilha das responsabilidades intrafamiliares entre homens e mulheres que pressupõe igualdade de oportunidades no mercado de trabalho. Estas partilhas devem ser debatidas no quadro de uma sociedade reflexiva onde os problemas políticos são também questões da vida quotidiana e das relações de género. ${ }^{14}$

${ }_{13}$ É a questão do "care" que se coloca aqui.

${ }^{14}$ Para um aprofundamento, ver I. Guérin, 2003 e 2007: 282-304. 


\section{O comércio justo}

Os serviços de proximidade inscrevem-se, por conseguinte, nesta longa história das iniciativas locais que remonta à economia popular. A maior novidade, em contrapartida, é o aparecimento de iniciativas que se desenvolvem no Norte e no Sul. Se as respostas são comparáveis, é porque as políticas neoliberais que se exercem no Sul e cujo conteúdo é sintetizado no consenso de Washington (abertura acentuada à concorrência internacional, recurso acrescido a mecanismos de mercado em detrimento da regulação pública e privatização dos serviços públicos), impregnam também as escolhas públicas no Norte.

A partir do início dos anos 1980, as instituições financeiras internacionais começaram a condenar as políticas industriais e sociais como ineficazes, dando a prioridade à liberalização das economias, ao saneamento das finanças públicas e à privatização dos serviços de saúde. A procura de soluções por parte dos governos para restaurar o crescimento recebe uma resposta de vocação universal, segundo o consenso de Washington: recurso acrescido a mecanismos de mercado livres de regulação estatal, intervenção pública mínima, abertura acentuada à concorrência internacional. O Banco Mundial e o Fundo Monetário Internacional ganham em importância ao condicionarem os seus apoios a políticas ditas de ajustamento estrutural. Corolário: o aumento das diferenças sociais, do desemprego e da pobreza no interior de cada país é tão sensível como o crescimento das desigualdades sociais a nível mundial.

Os países do Sul, dominados pelas oligarquias ligadas às elites do Norte, optaram, há muito tempo, por um modo de desenvolvimento dependente em relação às exportações de matérias primas e de produtos agrícolas. Desde a sua criação em 1994, a Organização Mundial do Comércio acentua a degradação dos termos de troca, porque os preços destes produtos tende a aumentar mais lentamente do que os preços dos produtos industriais do Norte. A abertura comercial praticada sem terem sido integradas normas sociais e ambientais vinculativas na legislação internacional, conjugada com o rigor orçamental a nível nacional, teve efeitos sobre muitas centenas de milhares de camponeses no mundo, sobretudo porque a redução das intervenções públicas se revela selectiva. A manutenção de subvenções fortes permite aos países ricos exportar a preços tão baixos que levam ao desaparecimento das produções locais. Ao mesmo tempo, constróise uma série de exigências técnicas como barreiras aduaneiras contra as importações. Na realidade, os poderes de negociação dos países são, no mínimo, díspares e as multinacionais interferem nos acordos internacionais, controlando metade e dois terços da produção e do comércio mun- 
diais. ${ }^{15}$ Segundo o Programa das Nações Unidas para o Desenvolvimento (PNUD), o comércio internacional é controlado a $82 \%$ por países onde vive um quinto da população mundial; os países do quinto mais pobre controlam pouco mais de $1 \%$. Os países em vias de desenvolvimento participam em cerca de $30 \%$ no comércio internacional de bens e estão ainda menos presentes nos fluxos financeiros e nos serviços.

É contra estas injustiças avalizadas, para não dizer aumentadas, pelas instituições internacionais que se constituiu o comércio justo, o qual procura submeter as relações comerciais ao respeito pelos produtores e à preservação do ambiente. Como os próprios afirmam, "os actores do comércio justo, apoiados por numerosos consumidores, empenham-se no apoio activo aos produtores, na sensibilização do público e na mobilização para alterar as regras e as práticas do comércio internacional convencional" ${ }^{16}$ Resultante do encontro de representantes do Sul, que exigem que a ajuda ao desenvolvimento seja convertida em práticas comerciais "justas", com associações do Norte ecologistas e defensoras dos direitos humanos, o comércio justo estabeleceu dois objectivos, desde o início:

- melhorar a vida dos pequenos produtores do Sul, marginalizados por falta de meios financeiros e de experiência, criando escoamentos para comercializar os seus produtos agrícolas ou artesanais junto dos consumidores do Norte desejosos de contribuir para uma maior solidariedade entre o Norte e o Sul;

- constituir uma rede de consumidores, através da sensibilização da opinião pública para as injustiças das regras do comércio internacional e da realização de acções junto dos decisores políticos e económicos. (Ritimo-Solagral, 1998: 15)

O primeiro modo de intervenção é a venda directa de produtos artesanais e agrícolas do Sul através das "lojas do mundo" ou "World Shops", surgidas nos Países Baixos desde 1969, por iniciativa de associações e cooperativas, nomeadamente de solidariedade internacional. Existem mais de 3.500 lojas em 18 países europeus, geridas por 60.000 voluntários e 4.000 assalariados. A sua taxa de crescimento é de $20 \%$ por ano, mas as disparidades nacionais permanecem fortes: o volume de negócios na Holanda é 500 vezes superior àquele que é realizado em França. Os produtos são importados pelas "Alternative Trading Organizations” (ATO). A primeira destas centrais de compras foi criada pela Oxfam em 1964 e, hoje, são mais de 100, sendo que as doze

${ }^{15}$ Como revela "Agir ici" 70\% da criação de frangos para consumo de carne do Senegal desapareceram devido à importação massiva de peças de frango da Europa (Campagne "Agir ici”, n. ${ }^{\circ}$ 68, Outubro 2004).

${ }^{16}$ Segundo FINE, agrupa quatro organizações internacionais representativas do comércio justo. 
mais importantes estão reunidas na "European Fair Trade Association" (EFTA) criada em 1990. A EFTA importa 60\% dos produtos equitativos na Europa, oriundos de 800 grupos de produtores do Sul, de 45 países diferentes, representando 800.000 famílias, ou seja, cerca de 5 milhões de pessoas. O papel da EFTA é de garantir o respeito de critérios nas compras e nas relações com os produtores: estabelecimento de relações duradouras e pré-financiamento da produção, limitação dos intermediários especulativos, controlo das condições sociais e ecológicas da produção, apoio aos projectos de desenvolvimento local, informação sobre o funcionamento do mercado internacional, pagamento de um "preço justo", que tenha em conta os custos e garanta um nível de vida razoável. Quinze federações de lojas do mundo de 13 países reuniram-se na Network of European World Shops (NEWS!) desde 1994, para harmonizar os progressos nacionais, ajudar na coordenação destes progressos e organizar campanhas europeias de sensibilização tendo como alvo tanto os consumidores como os poderes públicos.

Em 1988 nasceu, ainda nos Países Baixos, a iniciativa Max Havelaar que pretendia alargar a comercialização. O objectivo, que se difundiu em muitos países, entre os quais a França, era garantir o carácter equitativo de produtos pela atribuição de um rótulo. $\mathrm{Na}$ verdade, trata-se mais de uma certificação, uma vez que o rótulo propriamente dito pressupõe, na legislação francesa, um caderno de encargos para cada produto que é emitido por um organismo independente de controlo, bem como de um despacho de homologação dos poderes públicos. De seguida, surgem mais 16 associações nacionais na Europa, na América do Norte e no Japão. Em 1997, estas associações impulsionam a "Fair Trade Labelling Organizations International" (FLO International) para homogeneizar os standards por tipo de produto, apoiar o reforço das organizações de produtores e facilitar o acesso à comercialização dos seus produtos. A FLO International cobre nove fieiras: café, chá, cacau, açúcar, arroz, mel, frutos frescos, sumos de frutas e bolas de futebol. Envolve 357 organizações de produtores em 46 países do Sul, ou seja, cerca de 800.000 famílias. Os produtos estão presentes em 70.000 pontos de venda, entre os quais 50 das principais cadeias de grande distribuição e 33.000 supermercados de média dimensão.

Assim, as iniciativas variam, consoante se prefere a venda directa ou a certificação. Traduzem estratégias diferentes face aos consumidores. Os importadores-distribuidores, como as lojas do mundo, reagem contra um comércio no qual produtor e consumidor não se conhecem um ao outro. O essencial é dominar a fileira para remunerar melhor o produtor e recuperar a dimensão humana e cultural da troca, permitindo ao comprador 
compreender as condições em que o bem que adquire é produzido. $\mathrm{O}$ anonimato deve ser substituído por uma personalização, graças à qual a realidade das formas de vida nos países do Sul passa a ser perceptível para os consumidores do Norte. Para os organismos de certificação, a prioridade é não se limitar a compras militantes, mas divulgar o comércio justo ao grande público, colocando os produtos à sua disposição no maior número de pontos de venda.

Há tensões cada vez mais vivas entre estas orientações. Não obstante, instâncias de agrupamento internacional como a "International Federation for Alternative Trade", fundada em 1989, e a estrutura FINE, que reúne as organizações representativas (FLO, IFAT, NEWS! e EFTA), defendem as preocupações comuns a todas as componentes do comércio justo: contestar o peso desigual dos países no funcionamento actual da OMC, bem como a subordinação dos direitos sociais e ambientais aos direitos económicos, contestar a abertura sistemática do mercado, em detrimento da soberania alimentar. São estabelecidas alianças com os sindicatos e as associações de consumidores, ${ }^{17}$ com o objectivo de interpelar as empresas sobre as suas práticas sociais e as práticas sociais dos seus subempreiteiros, no que diz respeito a condições de trabalho "decentes", segundo as normas da Organização Internacional do Trabalho. São também realizadas campanhas para influenciar as legislações nacionais e internacionais.

Para não reproduzir o esquema do comércio convencional, segundo o qual os países do Sul não são mais do que fornecedores para o Norte, é importante incluir os trabalhadores do Sul na definição de critérios, na fixação dos preços e na avaliação das acções. É também importante estimular as fileiras de comercialização mais limitada, facilitando a concretização de formas de regulação pública sujeitas ao controlo simultâneo dos poderes públicos e das organizações da sociedade civil local. Deste ponto de vista, o comércio justo concebido a partir de uma crítica das relações Norte-Sul alarga-se a dinâmicas Sul-Sul e Norte-Norte. Os militantes têm como principal preocupação reduzir os custos ecológicos ligados ao transporte a grandes distâncias, bem como progredir no sentido de uma economia mais autocentrada no âmbito de regiões ou subregiões. Uma fórmula como a das "Associations pour le maintien d'une agriculture paysanne" (Associações para a preservação da agricultura camponesa) (AMAP), em França, ilustra o surgimento das redes Norte-Norte: um grupo de consumidores faz um contrato com um camponês, comprando

${ }_{17}$ Como acontece com o colectivo "De l'éthique sur l'étiquette" (Da ética na etiqueta) em França. 
antecipadamente a sua produção a um preço estabelecido de comum acordo, durante um período determinado e suficientemente longo para implicar uma partilha dos riscos. Os consumidores encontram-se regularmente com o produtor para se fornecerem de alimentos frescos e naturais, e uma comissão de voluntários assegura o funcionamento da associação. Esta perspectiva nova, que corresponde a um comércio justo local, também é impulsionada na América Latina, como se pode ver pelo "Encontro latino-americano sobre o comércio justo e o consumo ético na perspectiva da solidariedade global”, realizado em Lima, em 2001. Entre os sucessos destacados deste encontro figura a Rede Latino-Americana de Comercialização Comunitária (RELACC), que abrange 12 países. O seu objectivo é promover o aumento das trocas nacionais, diminuindo os intermediários, para os produtores, maioritariamente indígenas e de meio rural, poderem receber um preço melhor pelos seus produtos. Quanto aos consumidores, têm acesso a produtos de primeira necessidade a um preço razoável. No Peru, mais de 3000 restaurantes populares fornecem-se assim. Outro exemplo da dinâmica Sul-Sul é o rótulo "Comércio Justo México" para a comercialização no mercado nacional.

Como estas diversificações documentam, desde os anos 1990, o crescimento do comércio justo tem sido de tal forma espectacular que corre o risco de implosão. Com efeito, para algumas iniciativas, o aumento do volume de negócios foi avassalador, traduzindo, para elas, a tomada de consciência do poder dos consumidores. Outras recordam vigorosamente que as campanhas internacionais pela defesa dos direitos dos trabalhadores do Sul contam mais do que o volume das transacções. As acções de sensibilização são tão importantes como as trocas que devem, sem ceder à banalização, ${ }^{18}$ atingir um limiar suficiente para interpelar a realidade do comércio mundial. Apesar destas divergências, o impacto do comércio justo é inegável e não se limita aos sectores de actividade nos quais está implantado. As questões que este comércio coloca são multiplicadas por aquelas que são suscitadas do ponto de vista do consumo responsável e solidário $^{19}$ e transferem-se, igualmente, para outros domínios, associando-se àquelas que foram formuladas pelas redes de turismo equitativo e solidário (Collombon, Barlet e Ribier, 2004). Articulado com outros movi-

\footnotetext{
${ }_{18}$ Daqui resultam os debates sobre a comercialização limitada nas lojas do mundo, face à abertura à grande distribuição, ou sobre o equilíbrio voluntariado-profissionalização. Para o caso francês, cf. as publicações da Fédération Artisans du Monde (Federação Artistas do Mundo) que difunde igualmente aquelas que são editadas pelo colectivo "De l'éthique sur l'étiquette" (Da ética na etiqueta).

${ }^{19}$ Sobre o consumo responsável e solidário, ver também E. Mance, 2006.
} 
mentos que actuam no mesmo sentido, como as microfinanças, o comércio justo contribui para contestar aquilo que veio a constituir o dogma do livre-câmbio.

\section{Microfinanças e moedas sociais}

Não é uma coincidência, mas a reacção a um mesmo processo de desregulação: no momento em que o comércio justo protesta contra a marginalização crescente dos pequenos produtores, procuram-se vias de um financiamento popular para encontrar soluções para a exclusão bancária, da qual são vítimas numerosos empresários no circuito que podemos, apesar de tudo, qualificar de convencional. Em particular através das intervenções de organizações não governamentais, são elaborados mecanismos de apoio para ajudar à criação de actividades.

Um dos principais é o microcrédito. Concebido para lutar contra a pobreza, o seu sucesso rápido faz dele um instrumento simples que é apresentado como solução para as categorias desfavorecidas. As cimeiras mundiais do microcrédito fixam como alvo o número de 100 milhões de clientes, revelando um entusiasmo que não deixa de ter algumas ambiguidades, por duas razões principais: a redução da iniciativa a um modelo único, a utilização do tema da iniciativa para alimentar a crítica do sistema salarial.

Em primeiro lugar, o conjunto das iniciativas é reduzido ao modelo único do empresário individual. A capacidade de iniciativas que surge na sociedade é limitada a um "capitalismo de pé descalço" (De Soto, 1987) que não se apercebe da diversidade dos processos reais. Com efeito, como revelaram pesquisas realizadas nos países do Sul, a economia popular não pode ser interpretada nestes termos. Algumas iniciativas de mulheres (Guérin, 2003) são exemplos sintomáticos deste ponto de vista, pois não podem ser analisadas através do modelo de empresa individual: geralmente inserem-se numa iniciativa colectiva para o melhoramento da vida quotidiana. As mulheres que nelas participam empenham-se em sectores ligados à vida quotidiana, convertendo os seus saberes tradicionais em competências profissionais. No Norte, existem também iniciativas semelhantes: por exemplo, restaurantes de bairro, serviços de catering, serviços de mediação... A originalidade destas iniciativas tem a ver com a sua dimensão colectiva e o que está em jogo tem a ver com economia e cidadania. A sua motivação é a vontade de serem actrizes das suas próprias vidas e da transformação social. Actualmente, a multiplicação das iniciativas empresariais de grupos de mulheres debate-se com problemas de reconhecimento e de credibilidade, limitando assim a sua concretização e a sua durabilidade. Reconhecer às iniciativas de 
mulheres, como a outras iniciativas, a sua capacidade de inovação pressupõe a integração das suas formas de organização colectiva (Berger, Fraisse e Hersent, 2000).

Outro traço marcante: a multiplicação das micro-empresas independentes é apresentada como uma alternativa às regras protectoras do sistema salarial. Segundo esta análise, a intervenção do Estado, que engendrou uma rigidez prejudicial, deve ser substituída pela acção de um sector privado motivado por uma preocupação de bem-estar social. É, por conseguinte, a apologia da não intervenção do Estado que sustenta o discurso sobre a micro-empresa. A ficção da igualdade contratual dos indivíduos é utilizada, como acontecia no século XIX, para mascarar as relações de força que se instituem entre contratantes em posições assimétricas. Ora, esta leitura ideológica também é infirmada pelos factos. De facto, as experiências de apoio às iniciativas que se impuseram clamam por relações de confiança $\mathrm{e}$ por uma territorialização da acção. A mediação associativa aparece, portanto, como indispensável. Para além disso, actualmente, nenhuma experiência se pode considerar inteiramente pública ou inteiramente privada. Se os financiamentos públicos se revelam indispensáveis, para o meio associativo uma maneira de limitar a dependência relativamente aos fundos públicos consiste em desenvolver parcerias bancárias através de fundos de garantia. Os dispositivos de crédito solidário que pretendiam ultrapassar o estádio experimental escolheram esta via.

Uma parte dos organismos que surgiram no Sul distanciou-se, por conseguinte, desta referência ao microcrédito como panaceia. Progressivamente, experiências mais críticas do sistema bancário e mais viradas para um combate contra as razões estruturais das desigualdades distinguem-se do microcrédito, com o objectivo de defender uma posição mais política e menos funcional, afirmando os seus empenhamentos solidários e concebendo as suas práticas como uma nova forma de acção colectiva e de intervenção pública (Servet, 2006: 439-465). Praticando igualmente empréstimos sem poupança prévia, as microfinanças solidárias singularizam-se pelo tipo de entidades apoiadas, pelas operações efectuadas e pelos recursos mobilizados. Abrem-se tanto a empresas colectivas como a actividades que tenham um fim ecológico ou social, juntam à ajuda em forma de crédito outros serviços (garantia, capital de risco, seguros...) e um investimento na fase de acompanhamento dos projectos, combinam drenagem da poupança, na qual os subscritores podem renunciar voluntariamente a uma parte da sua remuneração, e participação de fundos públicos. Em suma, estas iniciativas inserem as intervenções financeiras num processo de socialização que as distingue de um microcrédito indiferente à utilidade da produção e centrado 
sobre a figura do empresário individual. Nesta base, as finanças solidárias conquistam os países do Norte. Assim, na Europa, a Fundação Europeia de Finanças e de Bancos Éticos e Alternativos agrupa, desde 2001, instituições de dez países europeus. Tem como objectivo promover a poupança e o investimento solidário, em primeiro lugar, através de uma fiscalidade favorável. Um dos promotores é a "Banca popolare Etica" em Itália, ponto de encontro entre investidores que partilham a exigência de uma gestão mais responsável e consciente do seu dinheiro com iniciativas socioeconómicas que subscrevem os princípios de um modelo de desenvolvimento humano e social sustentável. No momento do depósito do seu dinheiro, o aforrador pode escolher as áreas de actividade às quais deseja destinar os seus fundos: serviços socio-sanitários e educativos; luta contra a exclusão social; salvaguarda do ambiente e dos bens culturais, cooperação para o desenvolvimento e ajuda internacional; comércio justo; qualidade de vida, promoção do desporto para todos e iniciativas culturais.

Existe na Europa uma história dos bancos "sociais" que se caracteriza por uma preocupação pelas populações e territórios desfavorecidos e uma vontade de acesso às finanças para todos: falamos das caixas de crédito municipais, dos bancos mutualistas e cooperativos, das caixas de aforro sob forma de estabelecimentos públicos no Luxemburgo, de fundações municipais na Alemanha, de administrações na Grécia e em Portugal, de estabelecimentos com fins não lucrativos e cooperativas em França (Glémain, 2006). Perto de $54 \%$ dos bancos sociais na Europa são caixas de poupança e 18\% do mercado bancário europeu é constituído pelos bancos cooperativos (Richez-Battesti et al., 2006). Mais precisamente, o movimento actual renova a ligação com a ideia de crédito popular presente em meados do século XIX em França com o projecto de banco de câmbio de Proudhon, na Alemanha com a caixa de crédito agrícola mutual de Raffeisen e o banco popular de Schulze-Delitzsch, e, mais tarde, no Reino Unido, com as "credit unions". Esta nova ligação faz-se através do regresso aos objectivos originais por parte dos bancos cooperativos e mutualistas antigos, bem como através do surgimento de novos operadores. No primeiro caso, podemos citar o "Cooperative Bank". Fundado em 1872, parecia votado a um declínio irremediável em 1990, quando, para grande surpresa do próprio movimento cooperativo, se rebaptizou "banco ético" e superou uma tentativa de desmutualização a partir da assunção desta referência (S. Yeo, apud Taylor, 2004: 134). No segundo caso, podemos mencionar, em França, onde somente $22 \%$ das empresas criadas de novo obtêm um financiamento bancário (Alcoléa-Bureth, 2004: 245-292), instituições que intervêm através da participação no capital e de empréstimos, ao nível regional, como Femu 
Qui, na Córsega, ou Herrikoa, no País Basco, e, ao nível nacional, a Nouvelle économie Fraternelle (NEF) ou os Clubs d'investisseurs pour une gestion alternative et locale de l'épargne (Clubes de investidores para uma gestão alternativa e local da poupança) (CIGALES). Para estes últimos, a sua federação reivindica o apoio a mais de 350 empresas e a criação de 1.800 empregos com 12 milhões de euros investidos. No que diz respeito ao capital de risco de proximidade e solidário, reúne 7.000 accionistas para cerca de 6 milhões de euros e apoia 650 empresas. Desde 1995, a associação Finansol, ou seja, Finanças e Solidariedade, reúne as experiências para as dar a conhecer melhor. Apesar de uma certa heterogeneidade, os organismos de Finansol entendem-se maioritariamente como instrumentos que, para combater a polarização entre ricos e pobres, não podem limitar-se às ajudas individuais e devem reforçar as redes sociais protegendo os mais fracos e as suas acções colectivas.

Esta concepção do dinheiro ao serviço dos laços sociais prolonga-se nas trocas de bens, de serviços ou de saberes organizados por meio de moedas sociais (Blanc, 2006). Já não se trata da democratização do acesso à moeda oficial, mas da criação de uma unidade de cálculo entre os aderentes de uma mesma associação. Ao contrário das moedas nacionais, as moedas sociais, emitidas por um grupo de cidadãos que lhes atribui um nome, são moedas que escapam aos monopólios estatais. Destinam-se a desenvolver as relações interpessoais, constituindo espaços de confiança onde se debatem as regras das trocas, o que permite valorizar as capacidades locais, para lá daquelas que são mobilizadas pela produção mercantil. A ideia genérica consiste em substituir a troca contratual baseada na independência individual por uma inscrição numa rede social que pretende ser convivial e na qual podem efectuar-se trocas multilaterais, tecendo laços de clientela ${ }^{20}$ entre todos os membros, os quais perduram após a transacção e incitam à renovação das alianças. As moedas sociais não existem antes da troca: são direitos de emissão e a sua circulação é encorajada em detrimento do entesouramento, por exemplo, quando assumem a forma de moedas "que se fundem”, isto é, relativamente às quais a acumulação e a detenção são penalizadas com uma diminuição de valor.

Estas moedas tiveram precedentes. Um dos mais célebres registou-se na década de 1930, na Áustria, onde foi criada uma moeda local para lutar contra a depressão económica. Esta moeda seria proibida pelo banco central. Também existiram moedas locais nos anos 1950, na França e no Brasil,

${ }^{20}$ Sobre a diferença, no contexto do vocábulo "mercado", entre "lugar do mercado" e uma relação de "laços de clientela", cf. Servet, 2006: 314-316. 
mas a sua expansão contemporânea é muito mais marcada: surgidos em 1983, os "Local Exchange Trading Systems" envolvem, segundo os poucos dados conhecidos, mais de 1,5 milhões de aderentes repartidos por mais de 2.500 associações numa trintena de países, sobretudo no Ocidente, na América Latina e no Japão.

Em determinados sistemas, como os Bancos do tempo italianos, os sistemas de trocas locais (SEL) franceses e os Tauschringe alemães, a equivalência da unidade escolhida com a moeda nacional é recusada, uma vez que o objectivo é promover um sistema de valores diferente. Recuperando uma linha de força da primeira metade do século XIX, posta em prática nos mercados owenianos do trabalho equitativo, estes sistemas transferem para o trabalho a integralidade do valor e dos serviços, sem fazer qualquer tipo de pré-levantamentos. É o tempo gasto que conta num quadro que revela uma identidade comum e, para o funcionamento ser dinâmico, o empenhamento nas actividades deve ser repetido regularmente. Para impulsionar estas relações igualitárias e participativas, os encontros e o espírito lúdico são alimentados através dos nomes evocativos atribuídos à unidade monetária e pela frequência das bolsas de trocas. Os LETS dos países anglo-saxónicos, como a Austrália, o Canadá, a Nova Zelândia, ou o Reino Unido, têm um objectivo ligeiramente diferente. Como as finanças solidárias, eles contestam, prioritariamente, a exclusão que resulta da ortodoxia monetária e focalizam a sua acção sobre o incentivo de meios de pagamento que possam ir ao encontro da restrição da massa monetária. Neste contexto, é lógico que a moeda social seja parcialmente convertida em moeda nacional e que sejam criadas oportunidades de trocas inter-LETS. Trata-se menos de procurar práticas com fundamentos diferentes, e mais de atingir uma inserção em fluxos económicos, cujo volume está a aumentar.

O alargamento rápido de todos os sistemas de trocas locais alimentou certas interpretações, segundo as quais estes sistemas eram considerados como os vectores de uma economia espontânea de entreajuda mutualista. Em 2002, a Argentina contava mais de 5 milhões de membros, mas este crescimento durou pouco e seguiu-se o desmoronamento. Exceptuando esta situação particular, o ciclo típico é menos irregular: à construção acelerada seguiu-se sobretudo uma certa desaceleração, como aconteceu em França, onde o número de SEL parou de crescer em 1998, para regredir ligeiramente: cerca de 315 SEL para 30.000 membros em 2000. Os factos substituem o sonho de um novo paradigma para a sociedade por uma capacidade de intervenção mais modesta que contribui para legitimar iniciativas na economia, independentemente da posse de um capital. Desta perspectiva, os sistemas de câmbios locais são próximos de outras expe- 
riências que se libertam da passagem pela moeda oficial nas trocas que suscitam. Dois exemplos podem ser citados nos países francófonos: o primeiro é o das redes de autoprodução acompanhada que começam a associar-se: oficinas de bairro, cozinhas colectivas, jardins-de-infância familiares, auto-reabilitação e auto-construção de habitação, lazer, reparações. ${ }^{21}$ Os apoios podem ser de ordem muito diversa e as aproximações não são, por isso, imediatas mas derivam todos da auto-produção, no sentido de actividades destinados a produzir bens e serviços para consumo próprio e da vizinhança (Cérézuelle, 2004: 101-108). O segundo exemplo é o das redes de trocas recíprocas de saberes, as quais se estruturaram em movimento há já vários anos (Héber-Suffrin, 1998: 417). Cada uma destas redes propõe estabelecer relações entre quem oferece e quem procura saberes de todo o tipo, não hierarquizados: "dos saberes funcionais (saber preencher formulários...) aos saberes clássicos (literatura, instrumentos musicais...) ou ainda ao saber fazer (utilização de software informático, cozinha, jardinagem...)" (Héber-Suffrin, 1992). Neste dois exemplos, como no caso dos sistemas de trocas locais, o quadro associativo é concebido como "uma tentativa de reequilíbrio permanente, de criação de coerência entre a actividade e a igualdade, numa tensão construtiva e cognitiva” (Héber-Suffrin, 1998: 214).

\section{Um novo questionamento sobre a economia}

Economia popular, serviços de proximidade, comércio justo, microfinanças e moedas sociais, o parentesco existente entre todas estas iniciativas é confirmado pela existência de experiências multidimensionais que incluem elementos das diferentes vias. Assim, no Peru, Villa el Salvador, bairro da lata de 350.000 habitantes perto de Lima, é uma colectividade autogerida que criou, em 1987, um parque industrial em conjunto com os representantes do governo nacional. Este pólo de desenvolvimento da economia popular, englobando financiamentos, formação, ajuda à comercialização e assistência técnica, gerou 30.000 postos de trabalho repartidos por 8.000 pequenas empresas. No Brasil, a associação dos habitantes do conjunto de habitações Palmeiras numa favela na periferia de Fortaleza celebrizou-se com o nome do seu banco popular - Palmas - que apoia o artesanato, a confecção, o fabrico de artigos de couro e de material de limpeza, bem como uma agência de turismo. A estas finanças solidárias, com uma moeda social própria do bairro, junta-se o comércio justo sob a forma de uma loja onde os produtores do bairro podem expor e vender. Em todos os casos, a fixação das regras económicas inclui a voz daquelas e daqueles cuja expressão

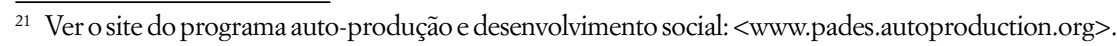


é habitualmente excluída pelas relações de força de uma economia dominada pelas lógicas de poder dos grandes grupos: as mulheres, os meios populares, os pequenos produtores do Sul...

Nestas irrupções associativas das últimas décadas do século XX, não se trata, pois, de defender uma economia ideal, inalcançável. ${ }^{22}$ A qualificação de economia alternativa, ainda marcada pelo imaginário de ruptura, tão acentuado no século XX e mobilizador durante algum tempo, esfumou-se. Foi substituída por significantes variados que remetem para iniciativas de categorias diversas.

\section{Da alternativa à busca de legitimidade}

É o que demonstram claramente as evoluções ao longo do tempo. Os primeiros projectos de serviços de proximidade situam-se num imaginário alternativo. Depois de 1968, o movimento das "creches selvagens" nascido em Paris multiplica-se em França e noutros países como a Alemanha, onde se criam as "lojas infantis" de Berlim. As creches selvagens ostentam a sua atitude contra-cultural e os seus objectivos anti-institucionais, rejeitando os outros locais de guarda colectiva de crianças e o domínio das instituições consideradas como nichos da ideologia dominante. A "vontade de independência e o desejo de poder, com toda a liberdade, formular a procura de uma nova expressão pedagógica e relacional mantiveram os grupos existentes à margem das instituições públicas sentidas como exercendo obrigatoriamente um poder de controlo e de normalização" (Passaris, 1984: 2). Na Alemanha, segundo um inquérito realizado em 1987 pelo Gabinete Nacional de Informação e de Ligação para o Desenvolvimento e o Apoio dos Grupos de Auto-Assistência, a primeira geração dos grupos de auto-assistência constituiu-se através de diferenciações progressivas no seio de dinâmicas contestatárias que procuravam, no plano local, produzir uma contra-sociedade.

A trajectória destes grupos é, nesta perspectiva, emblemática dos serviços de proximidade. Nestes locais de guarda de crianças, a face oculta da alternativa foi descoberta sem ter sido prevista: fraqueza de meios, isolamento, precariedade das acções, taxa de rotação dos voluntários, amplitude das

\footnotetext{
${ }^{22}$ A este respeito, algumas apresentações são demasiado datadas e demasiado influenciadas apenas pelo exemplo dos sistemas de trocas locais. Assim, no livro de F. Cusin e D. Benamouzig, 2004, devemos notar a referência que lhes é feita, mas temos também que refutar a avaliação que os autores propõem, em jeito de generalização, quando escrevem "coloca-se a questão da disponibilidade ou não de generalizar este sistema alternativo ao mercado" (208). Se a questão for colocada nestes termos, a conclusão não pode ser senão a invalidação de um projecto irrealista. A escolha entre "transacções mercantis ou lógicas de doação?", para retomar a terminologia dos autores, é enviesada, como demonstra a posição mais matizada de G. Simmel apresentada mais abaixo.
} 
responsabilidades face às gratificações retiradas da experiência. O esgotamento provocou o desaparecimento de muitas tentativas. Porém, apesar dos abandonos, a força delas consistiu em relativizar e contextualizar a utopia inicial, sem renunciar a ela. Uma vez que o objectivo se limitava a lançar serviços num domínio circunscrito, a reorientação foi mais fácil do que nalgumas experiências de partilha comunitária da vida e do trabalho, as quais deram lugar ao conflito interpessoal, à medida que as transformações projectadas fraquejavam. Em suma, a utopia foi o fermento de uma dinâmica que os desenvolvimentos de cada um dos projectos temperaram fortemente de realismo, uma evolução que a crise "económica" favoreceu, colocando em primeiro plano preocupações como a manutenção de serviços colectivos acessíveis a todos e a criação de emprego. "Por um lado, para os pais, tornou-se cada vez mais difícil arranjar simultaneamente tempo para participar no funcionamento das creches e dinheiro para o seu auto-financiamento", "por outro lado, a importância da estabilidade de um emprego assalariado também se fez sentir" (ibid.).

Assim, estas experiências registaram duas vagas: a da alternativa ao consumo mercantil e, depois, a do empirismo face aos problemas de emprego e da coesão social. Na sua procura de sentido, são testemunhos da crise de valores expressa no final da década de 1960; através do seu empirismo, interiorizam os obstáculos produzidos pela crise financeira que se seguiu. Esta dupla filiação traduz-se na referência a valores gerais articulada com a vontade de resolução de problemas concretos num domínio determinado.

A primeira vaga associativa introduziu uma lógica de tomada da palavra: a participação directa dos trabalhadores e dos utilizadores tornou-se pertinente para completar a participação consentida aos respectivos representantes.

A segunda vaga associativa é mais reactiva ao neoliberalismo e mais pragmática. Por esta razão, é objecto de apreciações ambivalentes da parte dos defensores do Estado social que ali descortinam, muitas vezes, o elogio da sociedade civil como substituto da intervenção estatal. A reivindicação de tomada da palavra por parte do cidadão é confundida com uma deserção do Estado, poder-se-ia dizer. Contudo, se as pressões exercidas pelos constrangimentos orçamentais do Estado social intervieram na génese dos serviços de proximidade, não explicam inteiramente o empenhamento de actores da sociedade civil. Este está igualmente ligado à promoção de formas de cidadania activa. Por outro lado, a maior parte das iniciativas não cauciona o fim do envolvimento do Estado: pelo contrário, procuram um reconhecimento público. Este reconhecimento começou a acontecer na sequência dos estudos que descreviam detalhadamente os conteúdos dos 
serviços de proximidade nos diferentes países da União, os quais viriam a ser financiados por programas piloto europeus sobre a inovação e o desenvolvimento rural (programa de iniciativa comunitária Leader), sobre o "terceiro sistema" (Direcção Geral de Emprego e Assuntos Sociais), sobre as estratégias regionais e locais de apoio à criação de empregos de iniciativa local e sobre as estratégias urbanas integradas e inovadoras de revitalização e conversão (artigo $10^{\circ}$ do Fundo Europeu de Desenvolvimento Regional). No total, pelo menos entre 5.000 e 6.000 experiências são apoiadas, o que testemunha da visibilidade progressiva de iniciativas ignoradas no passado. Todavia, estes apoios não conduziram a um lugar em linhas orçamentais estáveis. Esta ausência deve-se à inclinação no sentido do mercado, revelada pelas acções públicas ao nível europeu, as quais confundem, há muitos anos, o apoio a um domínio de actividades e a criação de um mercado novo, desenvolvimento territorial e ajuda às empresas. Por outro lado, a regulação pública concentrou-se sobre o objectivo de criação de empregos, preferindo as exonerações concedidas aos consumidores às subvenções da oferta e abandonando progressivamente a preocupação de acessibilidade que era constitutiva dos serviços sociais.

O reconhecimento encontra ainda um obstáculo que tem a ver com a utilidade social ou com o cariz quase colectivo próprio dos serviços de proximidade. Com efeito, muitos destes serviços, sendo individuais, uma vez que se dirigem a consumidores individuais, apresentam, igualmente, benefícios para a colectividade. O exemplo-tipo que obriga a ultrapassar a distinção entre serviços individuais e colectivos é o da guarda de crianças. Os modos de guarda de crianças estão muito ligados à concepção do papel e do lugar das mulheres na sociedade. Estes serviços têm consequências sobre o modo de vida dos indivíduos e nota-se que a colectividade tem uma influência sobre a maneira como se fazem escolhas que parecem muito individuais. Assim, os poderes públicos estão habilitados a intervir no financiamento da guarda das crianças pequenas por razões de equidade, entre as quais a vontade de tornar este serviço acessível ao maior número de pessoas e o controlo da qualidade dos serviços, e por razões externas ligadas aos benefícios que daí podem advir para a comunidade, nomeadamente uma maior disponibilidade das mulheres no mercado de trabalho ou um papel educativo e preventivo das estruturas de guarda (Fraisse, Gardin e Laville, 2000). O desafio que estas iniciativas e os respectivos interlocutores públicos enfrentam consiste na elaboração de fórmulas institucionais que tenham em conta os benefícios colectivos criados por determinados serviços, bem como o respeito por critérios de justiça social e de igualdade profissional. Entre os interesses individual e geral, o desafio é definir os critérios 
de utilidade social que criem o direito ao financiamento público e que possam ser objecto de uma negociação civil, alargando a negociação social a parceiros associativos e a colectividades locais.

Fundamentalmente, porém, o eco ainda fraco destas iniciativas deve-se ao facto de elas retomarem, ao ganharem amplitude, os modelos pré-estabelecidos da acção mercantil ou estatal. É o problema das diferenças de lógicas entre estas acções micro-colectivas e as regulações macro-institucionais. As iniciativas estudadas recompõem, através de acções micro-colectivas, as relações entre o social e o económico. As regulações macro-institucionais dominantes, por seu turno, continuam a justapor políticas económicas que justificam as medidas desreguladoras com o argumento da dureza da concorrência internacional e políticas sociais que tentam atenuar a fragmentação social acentuada pelas políticas económicas. As inadequações não podem deixar de estar patentes entre acções onde há vontade de organizar as condições de vida em função das razões de viver (De Certeau, 1980) e regulações herdadas de uma sociedade económica centrada na resolução do problema da raridade. É por esta razão que, perante a falta de debate social sobre as mediações institucionais susceptíveis de acompanhar o aumento de incertezas contemporâneas e face à incapacidade das regulações macro-institucionais de assegurar a coesão social, as acções micro-colectivas constituem fenómenos negligenciados, apesar da sua difusão relativa. Paradoxalmente, as mudanças institucionais que elas próprias provocaram permanecem da ordem da adjunção de procedimentos à margem, ao passo que o questionamento que protagonizam toca as escolhas fundamentais da sociedade. Muitas vezes, as associações são acusadas de favorecer a precariedade do emprego. Porém, antes de pôr em causa os actores, não seria melhor interrogarmo-nos sobre o défice e a recusa de reconhecimento público?

O que norteia os projectos associativos e cooperativos citados não é a vontade de limitar a acção pública. Pelo contrário, os seus responsáveis insistem no carácter indispensável da acção pública, mas acrescentam que as políticas públicas são levadas a repensar os respectivos modos de intervenção para integrar as iniciativas que têm como objectivo uma democratização da sociedade. O desafio é definir políticas que as apoiem devido aos seus contributos, não apenas nos planos económico e social, mas também no plano político, uma vez que elas estimulam uma aprendizagem da vida pública que favorece a tomada da palavra a propósito de problemas quotidianos. ${ }^{23}$

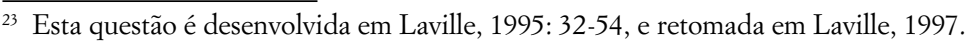




\section{Uma nova problemática}

Nenhuma destas iniciativas, validadas legalmente em diversos contextos nacionais, pode ser entendida através da abordagem do terceiro sector que estabelece uma separação estanque entre associações e cooperativas, a qual é cada vez mais posta em causa pela realidade. Também não cabe no âmbito dos estatutos da economia social adquiridos anteriormente: demarca-se destes devido aos seus objectivos solidários mais amplos, bem como devido à sua qualidade de empresa com múltiplas partes implicadas. O objectivo explícito de serviço à colectividade e a repartição do poder entre as diversas partes implicadas são as duas características mais específicas das realidades emergentes, o que obriga a examinar a respectiva ligação.

Regressemos, em primeiro lugar, aos objectivos. A partir do momento em que as actividades económicas são concretizadas como meios ao serviço de objectivos que se devem à solidariedade democrática, a produção de bens e de serviços obedece a uma outra lógica: não é decidida em função das perspectivas de lucro, mas sim a partir do seu carácter adequado a um bem comum. Os promotores insistem que as razões do seu empenhamento residem na procura de benefícios para a colectividade que não sejam efeitos induzidos da actividade económica, mas sim consequências intencionais. Assim, na agricultura biológica, nas energias renováveis ou na integração pelo económico, os custos ambientais ou sociais externalizados pelas outras empresas passam a ser internalizados. Os objectivos escolhidos pelos actores levam-nos a assumir funções como a manutenção do património local, a protecção do ambiente ou a integração no emprego de pessoas em dificuldades. No comércio justo, nas finanças solidárias, nos serviços de proximidade, o respeito pelos critérios de justiça social e de acessibilidade aos serviços também é uma constante.

A actividade não é concebida a partir de uma identidade comum préexistente, mas através de um reflexão colectiva que contribui para a definir. Para atingir os objectivos almejados, convém, por isso, usar os meios adequados: neste caso, estes meios residem no agrupamento das partes implicadas, para precisar as coordenadas de uma oferta e de uma procura que, anteriormente, não eram mais do que latentes ou vagamente evocadas. Assim, nos serviços de proximidade, não existem unicamente assimetrias de informação, como é estipulado na abordagem do terceiro sector, mas uma incerteza quanto à construção dos próprios serviços. O desafio comum das partes implicadas reunidas em torno do projecto é o tratamento desta incerteza informacional no quadro de uma procura explícita de justiça social - por exemplo, no acesso equitativo a serviços ou a um emprego "digno" 
(Laville e Nyssens, 2001: 9-21) - ou através da construção social daquilo que se designa externalidades positivas, na abordagem económica ortodoxa (Fraisse, Gardin e Laville, 2001: 192-207). A partir do momento em que estes benefícios deixam de ser um fenómeno induzido pela actividade económica, para passarem a ser uma dimensão reivindicada pelos promotores, é lógico que estes sejam recrutados entre os utilizadores e profissionais da actividade, aos quais se juntam, como voluntários, os parceiros que acreditam na legitimidade da iniciativa.

Logicamente, a procura de benefícios colectivos não atrai os investidores privados e a dinâmica de criação reside na mobilização de capital social. Podemos assim afirmar que o factor organizador, ou seja, segundo Razeto, o factor que determina os objectivos da entidade jurídica e que permite o respectivo controlo, é, neste caso, o capital social. Este capital pode, para além disso, ser designado mais especificamente como capital cívico (Evers, 2001), uma vez que procura benefícios colectivos, activando laços sociais democráticos. Se o capital social é importante em todo o processo produtivo, nas iniciativas consideradas, torna-se o factor organizador da produção e reveste-se de uma orientação cívica.

É isto que a perspectiva da economia solidária pretende testemunhar, quando insiste no projecto de democratização da economia que reúne todas estas iniciativas. Ou seja, usando a terminologia de Lipietz (2001), "fazemo-lo em nome disto" sobrepõe-se ao "como, sob que estatuto e com que normas de organização o fazemos", isto é, as regras da economia social. A economia solidária trouxe ao debate público as noções de utilidade social e de interesse colectivo e colocou a questão do objectivo das actividades que surgira de modo enganador na economia social centrada nas relações entre actividade e actores. Neste ponto, a economia solidária ultrapassa a economia social.

\section{Uma dupla dimensão}

A dupla dimensão, política e económica, reivindicada pela economia solidária e esquematizada no quadro abaixo, sublinha a necessidade de as experiências associativas, cooperativas ou mutualistas pesarem sobre os compromissos institucionais. A economia social, centrando-se sobre o aspecto organizacional, não foi capaz de contrariar o isomorfismo institucional criado pela divisão e complementaridade entre mercado e Estado social. Centrada no sucesso económico das empresas que a compõem, deixou de lado as mediações políticas. É, na verdade, como reacção aos efeitos perversos dessa focalização na dimensão económica que as experiências das últimas décadas reforçaram a dimensão política de iniciativas que preten- 
dem ser tanto cidadãs como empresariais. Estas não poderão ter alcance se não forem capazes de promover a democracia, tanto no seu funcionamento interno como na sua expressão externa.

\section{QUADRO - As duas dimensões da economia solidária}

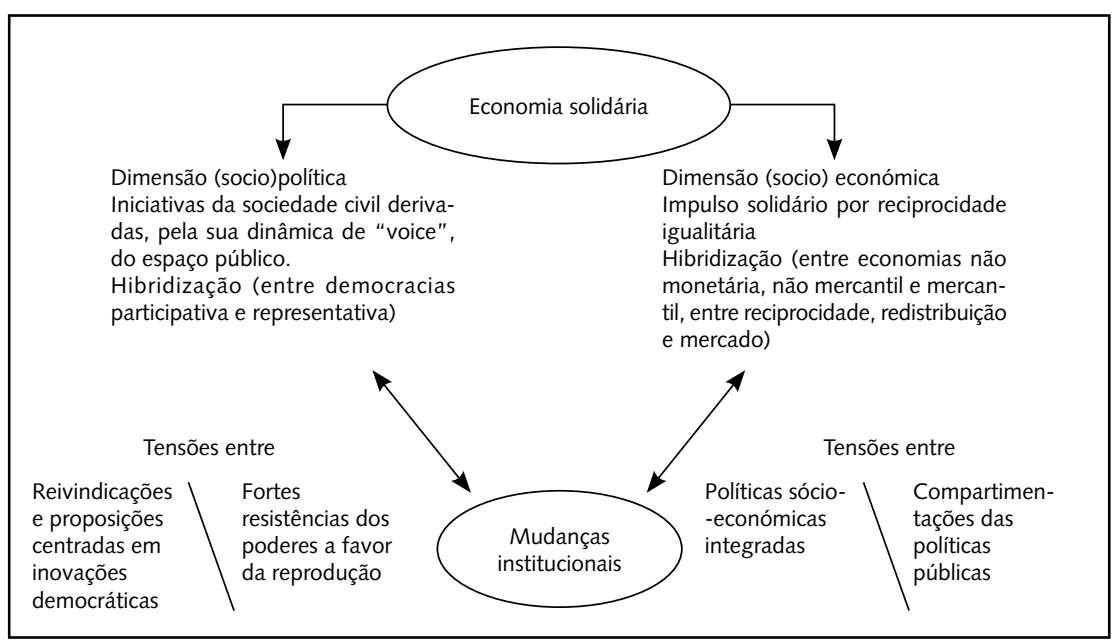

Admitir que o sucesso económico das experiências isoladas não é decisivo significa também levar a cabo uma reflexão sobre as razões pelas quais elas encontram tantos obstáculos à sua difusão. Nesta perspectiva, é preciso que haja uma definição dominante da economia que as discrimina negativamente. Se esta economia solidária não tem direito de existência plena, não se deve a insuficiências da parte dos seus actores, mas a uma razão mais fundamental. Pela sua dupla dimensão, a economia solidária interroga, ao nível conceptual e empírico, as categorias da economia, recusando limitar os fenómenos económicos àqueles que são definidos como tal pela ortodoxia económica. Interroga também este poder de delimitação que a ciência económica possui e alimenta uma reflexão mais geral sobre as definições e instituições da economia. ${ }^{24}$

${ }^{24}$ É nesta perspectiva que ela participa da sociologia económica, se, como defendem F. Cusin e D. Benamouzig (2004: 12), esta "não se subordinar às problemáticas próprias da teoria económica", suscitando "uma reflexão mais geral sobre o papel da economia nas sociedades modernas". 


\section{Referências bibliográficas}

Alcoléa-Bureth, A.-M. (2004), Pratiques et Theories de l'Économie Solidaire. Paris: L'Harmattan.

Autogestions (1981), "Les habits neufs du président Tito: Critique sociale, répression politique et luttes ouvrières en Yougoslavie", Privat, 6, Toulouse.

Berger, A.; Fraisse, L.; Hersent, M. (2000), "Femmes et économie solidaire”, Sciences de l'homme et sociétés. Cultures en mowvement, 31.

Blanc, J. (org.) (2006), Exclusion et liens financiers. Monnaies sociales. Rapport 2005-2006, Paris: Economica.

Carvalho, H. Martins de (2002), "A emancipação do movimento no movimento de emancipação social continuada”, in Boaventura de Sousa Santos (org.), Produzir para viver. Os caminhos da produção não capitalista. Rio de Janeiro: Civilização Brasileira, 233-260.

Cérézuelle, D. (2004), "Autoproduction et développement social", Hermès - "Economie solidaire et démocratie”, 36 .

Collombon, J.-M.; Barlet, S.; Ribier, D. (2004), Tourisme solidaire et développement durable. Paris: Les Editions du GRET.

Commission Européenne (1995), Les initiatives locales de développement et d'emploi. Bruxelles, Março.

Commission Européenne (1996), Le premier rapport sur les initiatives locales de développement et d'emploi. Des leçons pour les pactes territoriaux et locaux pour l'emploi, Document de travail des services de la Commission, Novembre.

Corpet, O. (1982), "Collectifs d'intervention et mouvements alternatifs", Communautés, 62, Outubro-Dezembro.

Corpet, O.; Hersent, M.; Laville J. L. (1986), "Le savoir sans privilèges", Revue internationale d'action communautaire, 15/5, Montréal.

Cusin, F.; Benamouzig, D. (2004), Economie et sociologie. Paris: Presses Universitaires de France.

Dahrendorf, R. (1972), Classes et conflits de classes dans la société industrielle. Paris-La Haye: Mouton.

De Certeau, M. (1980), La culture au pluriel. Paris: Christian Bourgois.

De Soto H. (1987), El otro sendero. Buenos Aires: Editorial Sud americana.

Defourny, J.; Favreau, L.; Laville, J. L. (1997), Insertion et nouvelle économie sociale. Paris: Désclée de Brouwer.

Demoustier, D.; Rousselière, D.; Clerc, J. M.; Cassier, B. (2003), "L'entreprise collective: Unité et diversité de l'économie sociale et solidaire", Revue internationale de l'économie sociale, RECMA, 82(290), 56-73.

Desroche, H. (1976), Le Projet Coopératif. Paris: Editions Ouvrières.

Eme, B. (2005), Sociologie des logiques d'insertion. Processus sociopolitiques et identités, Thèse de doctorat de sociologie. Paris: Sciences Po. 
Evers, A.; Laville J.-L. (orgs.) (2001), The Third Sector in Europe. London: Edward Elgar.

Evers, A.; Bode, I.; Gronbach, S.; Graf, A. (1999), The Enterprises and Organisations of the Third System: A Strategic Challenge for Employment. National Report Germany, CIRIEC, Working Group 1, Liège.

Folbre, N. (1997), De la différence des sexes en économie politique. Paris: Des Femmes.

Fraisse, L.; Gardin, L.; Laville, J. L. (orgs.) (2000), Le fonctionnement socio-économique du Troisième système. Recherche européenne pour la Direction de l'Emploi et des Affaires Sociales (DGV) de la Commission des Communautés Européennes.

Gardin, L. (2006), Les initiatives solidaires. Ramonville: Erès.

Gardin, L.; Laville, J.-L. (2000), Evaluation de la politique régionale de soutien au développement de nouvelles activités, nouveaux services. Paris: CRIDA.

Gendron, C. (2004), "Mouvements sociaux”, in J.-L. Laville; A. D. Cattani (orgs.), Dictionnaire de l'autre économie. Paris: Desclée de Brouwer, 395-402.

Glémain, P. (2006), Pour une sociologie économique des finances solidaires, Ecole doctorale Entreprise-Travail-Emploi. Paris: CNAM.

Guérin, I. (2003), Femmes et économie solidaire. Paris: La Découverte.

Guérin, I. (2007), "Economie solidaire et rapports de genre”, in J. L. Laville (org.), L'économie solidaire. Une perspective internationale. Paris: Hachettes Littératures, 282-304.

Héber-Suffrin, C. (1992), Échanger les savoirs. Paris: Desclée de Brouwer.

Héber-Suffrin, C. (1998), Les savoirs, la réciprocité et le citoyen. Paris: Desclée de Brouwer.

Hirschman, A. O. (1971), Exit, Voice and Loyalty: Responses to Decline in Firms, Organizations and States. Cambridge, Mass.: Harvard University Press.

Huber, J. (1981), "Projets auto-organisés et réseaux d'entraide”, Futuribles, 40, Janeiro.

Inglehart, R. (1977), The Silent Revolution - Changing Values and Political Styles among Western Publics. Princeton: Princeton University Press.

Jouen, M. (1995), Les initiatives locales de développement et d'emploi. Bruxelles: Commission Européenne, Março.

Klausen, K.; Selle, P. (1996), "The Third Sector in Scandinavia”, Voluntas, 7, 2.

Laville, J. L. (1995), "La crise de la condition salariale", Esprit - "Vers une société de pluriactivité?”, 12, Dezembro.

Laville, J. L. (1997), Le travail, quel avenir?. Paris: Gallimard.

Laville, J.-L.; Sainsaulieu, R. (1997), Sociologie de l'association. Paris: Desclée de Brouwer.

Laville, J. L.; Nyssens; M. (orgs.) (2001), Les services sociaux entre associations, Etat et marché. L'aide aux personnes âgées. Paris: La Découverte. 
Leichsenring, K. (1997), The Role of the Labour Market Service in Supporting NonStatutory Childcare Providers. Wien: European Centre for Social Welfare Policy and Research.

Lewis, J. (2003), “Gender and Welfare State in Change”, European Societies, 331-357. Lipietz, A. (2001), Pour le tiers secteur. L'économie sociale et solidaire pourquoi et comment. Paris: La documentation française-La Découverte.

Lorendahl, B. (1997), "Integrating the Public Sector and Cooperative Social Economy. Towards a Swedish New Model”, Annals of Public and Cooperative Economics, 68(3).

Mance, E. (2006), “Consommation solidaire”, in J. L. Laville; A. D. Cattani (orgs.), Dictionnaire de l'autre économie. Paris: Folio-Actuel, Gallimard.

Melucci, A. (1983), "Mouvements sociaux, mouvements post-politiques”, Revue internationale d'action communautaire, 10/50 (automne), 13-30.

Mothé, D. (2004), “Autogestion”, in J.-L. Laville; A. D. Cattani (org.), Dictionnaire de l'autre économie. Paris: Desclée de Brouwer, 53-60.

Navarro, Z. (2002), “'Mobilização sem emancipação' - as lutas sociais dos sem-terra o Brasil”, in Boaventura de Sousa Santos (org.), Produzir para viver. Os caminhos da produção não capitalista. Rio de Janeiro: Civilização Brasileira, 189-232.

Neveu, E. (1996), Sociologie des mouvements sociaux. Paris: Repères - La Découverte.

Nyssens M. (2006), Social Enterprise between Market, Public Policies and Civil Society. London: Routledge.

Passaris, S. (1984), La participation parentale dans les modes de garde de la petite enfance, 4 vol. Paris: CIRED, Ecole des Hautes Etudes en Sciences Sociales.

Pestoff, V. (1998), Beyond the Market and State: Social Enterprises and Civil Democracy in a Welfare Society. Aldershot, UK: Ashgate.

Pestoff, V. (2004), "The Development and Future of the Social Economy in Sweden”. Cheltenham, UK: Edward Elgar.

Prouteau, L. (org.) (2003), Les associations entre bénévolat et logique d'entreprise. Rennes: Presses Universitaires de Rennes.

Quijano, A. (1998), La Economia Popular y sus caminos en America Latina. Lima: Mosca Azul Editores.

Richez-Battesti, N.; Gianfaldoni, P.; Gloukoviezoff, G.; Alacaras, J. R. (2006), “Quelle contribution des banques coopératives à la cohésion sociale des territories. Une approche en termes d'innovation sociale", XXème colloque de l'ADDES, 7 Março, Paris.

Ritimo-Solagral (1998), Pour un commerce equitable. Paris: Éditions Charles Leopold Mayer, La Librairie Fondation pour le Progrès de l'Homme.

Rodriguez, C. (2002), “A procura de alternativas económicas em tempos de globalização: O caso das cooperativas de recicladores de lixo na Colômbia”, in Boaventura de Sousa Santos (org.), Produzir para viver. Os caminhos da produção não capitalista. Rio de Janeiro: Civilização Brasileira, 329-367. 
Scholnik, M. (1984), "Les organisations économiques populaires et la vie quotidienne”, Nouvelles de l'écodéveloppement, 31, supplément à MSH informations, Dezembro. Schumpeter, J. A. (1943), Capitalism, Socialism and Democracy. London: Allen and Unwin.

Servet, J. M. (2006), Banquiers aux pieds nus. La microfinance. Paris: Odile Jacob.

Taylor, M. (2004), The Welfare Mix in the United Kingdom. Cheltenham, UK: Edward Elgar.

Touraine, A. (1978), La voix et le regard. Paris: Seuil.

Verano, F. (2001), "La economia solidaria una alternativa de desarrollo con equidad y justicia social para construir la paz - un aporte para la reflexion y accion”. Bogotá: COLACOT (disponível online in http://groups.yahoo.com/group/rgses/files/ Economa1.doc).

Vienney, C. (1980-1982), Socio-économie des organisations cooperatives. Paris: Éditions CIEM, 2 vol. 